\title{
Bax Regulates Production of Superoxide in Both Apoptotic and Nonapoptotic Neurons: Role of Caspases
}

\author{
Rebecca A. Kirkland, Geraldine M. Saavedra, Brian S. Cummings, and James L. Franklin \\ Department of Pharmaceutical and Biomedical Sciences, The University of Georgia College of Pharmacy, Athens, Georgia 30602
}

\begin{abstract}
A Bax- and, apparently, mitochondria-dependent increase in superoxide $\left(\mathrm{O}_{2}^{-}\right)$and other reactive oxygen species (ROS) occurs in apoptotic superior cervical ganglion (SCG) and cerebellar granule (CG) neurons. Here we show that Bax also lies upstream of ROS produced in nonapoptotic neurons and present evidence that caspases partially mediate the pro-oxidant effect of Bax. We used the $\mathrm{O}_{2}^{--}$-sensitive dye MitoSOX to monitor $\mathrm{O}_{2}^{--}$in neurons expressing different levels of Bax and mitochondrial superoxide dismutase (SOD2). Basal and apoptotic $\mathrm{O}_{2}^{--}$levels in both SCG and CG neurons were reduced in SOD2 wild-type (WT) cells having lower Bax concentrations. Apoptotic and nonapoptotic neurons from Bax-WT/SOD2-null but not Bax-null/SOD2-null mice had increased $0_{2}^{--}$levels. A caspase inhibitor inhibited $\mathrm{O}_{2}^{--}$in both apoptotic and nonapoptotic SCG neurons. $\mathrm{O}_{2}^{--}$production increased when WT, but not Bax-null, SCG neurons were permeabilized and treated with active caspase 3 . There was no apoptosis and little increase in $\mathrm{O}_{2}^{--}$in SCG neurons from caspase 3-null mice exposed to an apoptotic stimulus. $0_{2}^{--}$levels in nonapoptotic caspase 3-null SCG neurons were lower than in WT cells but not as low as in caspase inhibitor-treated cells. These data indicate that Bax lies upstream of most $\mathrm{O}_{2}^{--}$produced in neurons, that caspase 3 is required for increased $\mathrm{O}_{2}^{--}$production during neuronal apoptosis, that caspase 3 is partially involved in $\mathrm{O}_{2}^{--}$production in nonapoptotic neurons, and that other caspases may also be involved in Bax-dependent $\mathrm{O}_{2}^{--}$production in nonapoptotic cells.
\end{abstract}

\section{Introduction}

Species of oxygen that are more reactive than dioxygen $\left(\mathrm{O}_{2}\right)$ are known as reactive oxygen species (ROS) (Punchard and Kelly, 1996). Biological organisms produce ROS by enzymatic mechanisms or as byproducts of mitochondrial metabolism. ROS have several physiologically important functions in cells but can also cause cellular injury if produced in excess (Halliwell and Gutteridge, 2007). ROS-induced oxidative stress is implicated in the neuronal damage occurring in ischemia (Abramov et al., 2007), Alzheimer's disease (Pratico et al., 2001; Lin and Beal, 2006), Parkinson's disease (Sherer et al., 2003; Keeney et al., 2006), and many other neuronal and non-neuronal pathologies (Halliwell and Gutteridge, 2007). Evidence also suggests that ROS have a role in the degenerative physical transformations occurring in the aging brain and other aging organ systems (Kokoszka et al., 2001; Pollack et al., 2002; Barja, 2004; Maklashina and Ackrell, 2004; Melov, 2004; Miller, 2004).

ROS include both free radical and non-free radical forms. The principal biologically produced free radical ROS is superoxide $\left(\mathrm{O}_{2}^{--}\right)$, and the major non-free radical ROS is hydrogen peroxide $\left(\mathrm{H}_{2} \mathrm{O}_{2}\right)$. A primary source of $\mathrm{O}_{2}^{--}$is the mitochondrial electron transport chain where a fraction of the $\mathrm{O}_{2}$ consumed is reduced to $\mathrm{O}_{2}^{--}$by electrons that leak from the respiratory complexes

\footnotetext{
Received June 4, 2010; revised Sept. 1, 2010; accepted Sept. 20, 2010.

This work was supported by National Institutes of Health Grant NS37110. We thank Kyndra Stovall for her insightful comments.

Correspondence should be addressed to James L. Franklin, Department of Pharmaceutical and Biomedical Sciences, The University of Georgia College of Pharmacy, 357 Wilson Pharmacy, Athens, GA 30602. E-mail: jfrankli@rx.uga.edu.

DOI:10.1523/JNEUROSCI.2862-10.2010

Copyright $\odot 2010$ the authors $\quad 0270-6474 / 10 / 3016114-14 \$ 15.00 / 0$
}

(Turrens, 1997; Liu et al., 2002; Andreyev et al., 2005). The $\mathrm{O}_{2}^{--}$ produced rapidly converts to $\mathrm{H}_{2} \mathrm{O}_{2}$ by a dismutation reaction catalyzed by superoxide dismutase (SOD) enzymes. The $\mathrm{H}_{2} \mathrm{O}_{2}$ can subsequently be converted to other ROS. However, most $\mathrm{H}_{2} \mathrm{O}_{2}$ rapidly converts to $\mathrm{H}_{2} \mathrm{O}$ via reactions catalyzed by the enzymes glutathione peroxidase and catalase.

Augmented production of ROS occurs in neurons undergoing apoptotic death (Tan et al., 1998). The increased ROS in apoptotic mouse superior cervical ganglion (SCG) and cerebellar granule (CG) neurons lie downstream of the proapoptotic protein Bax and appears to derive from the mitochondria electron transport chain (Kirkland and Franklin, 2001; Kirkland et al., 2002, 2007a,b). We previously provided evidence that these ROS are an important part of the apoptotic process in these cells (Kirkland and Franklin, 2001; Kirkland et al., 2002). Although a great deal is known about mechanisms for clearance of ROS from cells, very little is understood about how the production of ROS, particularly by mitochondria, is regulated (Halliwell and Gutteridge, 2007; Leitch et al., 2009). In this paper, we demonstrate that Bax lies upstream of most $\mathrm{O}_{2}^{--}$and other ROS produced not only in apoptotic but also in nonapoptotic SCG and CG neurons in cell culture. We also show that much of the pro-oxidant effect of Bax in apoptotic SCG neurons is mediated via activation of caspase 3 and that caspases in addition to caspase 3 may be involved in the pro-oxidant effect of Bax in nonapoptotic neurons. ROS, Bax, and caspases have all been implicated in many pathological conditions. Elucidation of the relationship between the three is important for understanding the etiology of these pathologies and may also contribute to an understanding of how healthy neurons regulate their redox state. 


\section{Materials and Methods}

Reagents. 5-(and-6)-Chloromethyl-2,7-dichlorodihydrofluorescein diacetate (CM- $\left.\mathrm{H}_{2} \mathrm{DCFDA}\right)$, MitoSOX Red, MitoTracker Green, rhodaminelabeled polydextran, and tetramethyl rhodamine methyl ester $\left(\mathrm{TMRM}^{+}\right)$were purchased from Invitrogen. Nerve growth factor 2.5S (NGF) was purchased from Harlan Bioproducts. Recombinant active mouse caspase 3 was obtained from MBL International. Recombinant truncated mouse Bax $\alpha$ (amino acids 38-171) was obtained from ProSpec-Tany TechnoGene Ltd. All other reagents were purchased from Sigma unless otherwise stated.

Mouse breeding and genotyping. DNA for genotyping was extracted from the tail of each mouse pup using a Wizard Prep kit (Promega) or a Quick Extraction kit (Epicenter Biotechnologies). Mice deficient in both bax alleles $\left(b_{a x}{ }^{-/}\right.$) breed poorly (female) or not at all (male) (Knudson et al., 1995). Therefore, mice hemizygous for the bax allele $\left(b_{a x}{ }^{+/-}\right.$; C57BL/6 genetic background) were mated to generate $\mathrm{bax}^{+/+}, \mathrm{bax}^{+/-}$, and $b a x^{-1-}$ offspring. Founding breeders were obtained from The Jackson Laboratory. Both the mutant and the wild-type alleles were amplified by a single PCR. Primers and PCR protocol have been detailed by Kirkland et al. (2002). Mice hemizygous for $\operatorname{sod} 2$ (Sod2 ${ }^{\text {tmlLeb }}$ in a C57BL/6 genetic background) were obtained from The Jackson Laboratory. $b a x^{+/-}$mice were crossed with the hemizygous $\operatorname{sod} 2\left(\operatorname{sod} 2^{+/-}\right)$mice to generate $b a x^{+/-} / \operatorname{sod}^{+/-}$breeders. Pups born to these breeders had the following genotypes: $\mathrm{bax}^{+/+} / \mathrm{sod} 2^{+/+}, \mathrm{bax}^{+/+} / \mathrm{sod}^{+/-}, \mathrm{bax}^{+/+} /$

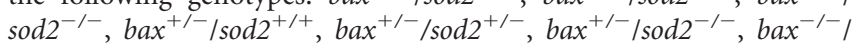
$\operatorname{sod} 2^{+/+}, \mathrm{bax}^{-/-} / \mathrm{sod}^{+/-}$, and $b a x^{-/-} / \mathrm{sod}^{-{ }^{-1}}$ in Mendelian ratios. PCR was used to amplify regions from both the wild-type and the mutant sod2 alleles. A forward primer (5'-GAA AGG ACG TTT ATG CGA ACC AAC- $\left.3^{\prime}\right)$ and a reverse primer (5'-GGC CTA CGT GAA CAA CCT CAA C-3') amplified a $134 \mathrm{bp}$ portion of the wild-type allele. In the same reaction tube, a forward primer (5'-CCA GTC TCA GGG GCA ACA AAG ATG-3') along with a mutant-specific reverse primer (5'-CGC CTA CCG GTG GAT GTG GAA TGT-3') generated a 311 bp product from the mutant allele. The cycling parameters were 4 min at $94^{\circ} \mathrm{C}$, followed by 35 cycles of $30 \mathrm{~s}$ at $94^{\circ} \mathrm{C}, 30 \mathrm{~s}$ at $59^{\circ} \mathrm{C}$, and $30 \mathrm{~s}$ at $72^{\circ} \mathrm{C}$. All newborn pups appeared healthy. However, mice with a sod2 $2^{-/-}$genotype typically died within 1 week of birth.

We purchased one male caspase 3 null mouse ( $\operatorname{casp} 3^{-/-} ; \operatorname{casp} 3^{\text {tm1Flv }}$ in a C57BL/6 genetic background) from The Jackson Laboratory. It was mated with female $\mathrm{C} 57 \mathrm{BL} / 6$ casp $^{+/+}$mice to generate casp $3^{+/-}$progeny. These mice were then crossed to produce $\operatorname{casp} 3^{+/+}, \operatorname{casp}^{+/-}$, and casp $3^{-/-}$offspring. A single PCR amplified regions from both the wildtype and the mutant casp 3 alleles. A forward primer (5'-GCG AGT GAG AAT GTG CAT AAA TTC- $\left.3^{\prime}\right)$ and a reverse primer (5'-GGG AAA CCA ACA GTA GTC AGT CCT- $3^{\prime}$ ) amplified a 320 bp portion of the wildtype allele. The same forward primer along with a mutant-specific reverse primer ( $5^{\prime}$-TGC TAA AGC GCA TGC TCC AGA CTG-3') generated a $300 \mathrm{bp}$ product from the mutant allele. The cycling parameters were 3 min at $94^{\circ} \mathrm{C}$, followed by 35 cycles of $30 \mathrm{~s}$ at $94^{\circ} \mathrm{C}, 1 \mathrm{~min}$ at $64^{\circ} \mathrm{C}$, and 1 $\min$ at $72^{\circ} \mathrm{C}$. This was followed by $2 \mathrm{~min}$ at $72^{\circ} \mathrm{C}$ to allow complete extension of amplification products.

Cell culture. SCGs were dissected from newborn mice. Neurons were enzymatically and mechanically dissociated from the ganglia and plated on an ammoniated collagen substrate as described (Martin et al., 1988; Deckwerth and Johnson, 1993; Franklin et al., 1995; Kirkland et al., 2002). Cells were cultured on \#1 glass coverslips (Bellco Glass) for microscopy experiments, on $35 \mathrm{~mm}$ plastic Costar tissue culture dishes (Corning) for immunoblot experiments and on 96-well culture dishes (Corning) for biochemistry experiments. Separate cultures were established from the ganglia of each pup from litters in which the pups could have different genotypes. Cells from one-half to one ganglion were plated per culture for most experiments. Cultures were maintained in a medium consisting of Eagle's minimum essential medium with Earle's salts (Invitrogen) supplemented with $10 \%$ heat-inactivated fetal bovine serum, $100 \mathrm{U} / \mathrm{ml}$ penicillin, $100 \mu \mathrm{g} / \mathrm{ml}$ streptomycin, $20 \mu \mathrm{M}$ fluorodeoxyuridine, $20 \mu \mathrm{M}$ uridine, $1.4 \mathrm{~mm}$ L-glutamine, and $50 \mathrm{ng} / \mathrm{ml} \mathrm{NGF}$. Apoptosis was induced by replacing the culture medium with the same one lacking NGF and containing an anti-NGF antibody (Cedarlane Labs) as described
(Kirkland et al., 2007b). Cultures were maintained at $35^{\circ} \mathrm{C}$ in an incubator having an atmosphere of $95 \%$ air and $5 \% \mathrm{CO}_{2}$.

Cultures of CG neurons were prepared as described (Miller and Johnson, 1996). Cells were dissociated from the cerebella of 7- to 10-d-old mice and plated $\left(\sim 2.5 \times 10^{5}\right.$ cells $\left./ \mathrm{cm}^{2}\right)$ on a poly-L-lysine $(0.1 \%)$ substrate coated onto \#1 glass coverslips (Bellco Glass) for microscopy experiments or onto $35 \mathrm{~mm}$ plastic Costar tissue culture dishes (Corning) for immunoblot experiments. Cultures were maintained at $35^{\circ} \mathrm{C}$ in an incubator with a $5 \% \mathrm{CO}_{2}$ and $95 \%$ air atmosphere in Basal Medium Eagle (Invitrogen) with $25 \mathrm{~mm} \mathrm{KCl}$ (to depolarize plasma membrane potential), $10 \%$ dialyzed fetal bovine serum (10,000 molecular weight cutoff), $50 \mathrm{U} / \mathrm{ml}$ penicillin, and $50 \mu \mathrm{g} / \mathrm{ml}$ streptomycin sulfate. Apoptosis was induced by repolarizing membrane potential by switching cultures to the same medium containing $5 \mathrm{~mm} \mathrm{KCl}$ and no serum. All SCG and CG neuron experiments were done with cultures from three or more platings that had been in culture for 6-9 d after plating.

Microscopy. Phase-contrast microscopy was done with a Nikon Eclipse TE 300 inverted microscope. Cells were observed with a $60 \times$-plan oilimmersion lens objective (numerical aperture 1.4), and images were collected by a cooled CCD camera (Micro-Max; Princeton Instruments) controlled by MetaMorph software (Molecular Devices) running on a Dell computer. Confocal microscopy was done with a Nikon C1 laserscanning confocal microscope mounted on the Nikon Eclipse TE 300 microscope. The confocal microscope was controlled by EZC1 software (Nikon) running on a Dell computer. The $60 \times$ objective was used to visualize neurons. Cells were scanned at $512 \times 512$ pixel resolution, except for those used for illustration, which were scanned at $2048 \times 2048$ pixel resolution. All confocal settings were maintained at a constant level during experiments.

ROS, mitochondrial membrane potential $\left(\Delta \psi_{m}\right)$, and MitoTracker Green measurements. We used the redox-sensitive dye CM- $\mathrm{H}_{2} \mathrm{DCFDA}$ to detect multiple ROS species. We extensively characterized the use of this dye in SCG and CG neurons (Kirkland and Franklin, 2001; Kirkland et al., 2002, 2007a,b). CM- $\mathrm{H}_{2}$ DCFDA becomes fluorescent when oxidized by $\mathrm{H}_{2} \mathrm{O}_{2}$ and ROS lying downstream of $\mathrm{H}_{2} \mathrm{O}_{2}$. It is also sensitive to oxidation by many other ROS and can be considered to be a generalized reporter for many different cellular ROS. It is relatively insensitive to oxidation by $\mathrm{O}_{2}^{--}$but is particularly sensitive to oxidation by $\mathrm{OH} \cdot$ (Royall and Ischiropoulos, 1993; Halliwell and Gutteridge, 2007; Kirkland et al., $2007 \mathrm{~b})$. Another major reactive species that potently oxidizes the dye is peroxynitirite $\left(\mathrm{NOO}^{-}\right)$. $\mathrm{NOO}^{-}$does not appear to be present in apoptotic SCG neurons. Nitric oxide synthase inhibitors have no effect on CM- $\mathrm{H}_{2}$ DCFDA-detected ROS in apoptotic SCG neurons (Kirkland and Franklin, 2001; Kirkland et al., 2002). Conversely, membrane-permeant polyethylene glycol (PEG)-catalase (Liu et al., 1989) completely suppressed these ROS, suggesting that the dye is being oxidized primarily by $\mathrm{H}_{2} \mathrm{O}_{2}$ or ROS derived from $\mathrm{H}_{2} \mathrm{O}_{2}$ (data not shown). CM- $\mathrm{H}_{2}$ DCFDA may detect this species in CG neurons. $\mathrm{CM}-\mathrm{H}_{2} \mathrm{DCFDA}$ is readily membrane permeant and is trapped in cells by binding to cellular thiols. Both SCG and CG neurons were loaded in the incubator for $20 \mathrm{~min}$ with $10 \mu \mathrm{M}$ $\mathrm{CM}-\mathrm{H}_{2}$ DCFDA in experimental culture medium, followed by two washes in Leibovitz L-15 medium. They were left in the last wash for microscopy. CM- $\mathrm{H}_{2}$ DCFDA was excited by the $488 \mathrm{~nm}$ line of the laser, and images were acquired with the green photomultiplier channel of the confocal microscope. We previously demonstrated that NGF-supported or -deprived $\mathrm{bax}^{+/+} / \mathrm{sod} 2^{+/+}, \mathrm{bax}^{+/-} / \mathrm{sod}^{+/+}$, and $\mathrm{bax}^{-/-} / \mathrm{sod} 2^{+/+}$ SCG neurons load equal amounts of this dye (Kirkland et al., 2002). These data demonstrate that the different Bax levels in the three genotypes did not interfere with the concentration of CM-H2DCFDA loaded into cells or with the ability of CM- $\mathrm{H}_{2}$ DCFDA to be oxidized. Supplemental Figure 1 (available at www.jneurosci.org as supplemental material) shows that $\mathrm{CM}-\mathrm{H}_{2}$ DCFDA loading and oxidation in SCG neurons were also not affected by altering both bax and sod genotypes.

Relative $\mathrm{O}_{2}^{--}$levels were determined with MitoSOX Red (Zhao et al., 2003, 2005; Ross et al., 2005; Robinson et al., 2006) as described (Kirkland et al., 2007b). MitoSOX consists of a triphenylphosphonium cation linked to hydroethidine. The cation moiety targets MitoSOX to the mitochondrial matrix because of the large $\Delta \psi_{m}$ across the inner mi- 
tochondrial membrane (IMM). MitoSOX localizes to mitochondria in mouse SCG and CG neurons (Johnson-Cadwell et al., 2007; Kirkland et al., 2007b). Oxidation by $\mathrm{O}_{2}^{--}$of the hydroethidine generates 2-hydroxyethidium that binds to mitochondrial DNA and fluoresces (Zhao et al., 2003, 2005; Ross et al., 2005; Robinson et al., 2006). We previously demonstrated that MitoSOX selectively detects $\mathrm{O}_{2}^{--}$in SCG neurons when excited with a 408 laser line (Kirkland et al., 2007b). Supplemental Figure 2 (available at www.jneurosci.org as supplemental material) shows that representative bax and sod2 genotypes investigated in this study had equal amounts of mitochondrial DNA. Therefore, the differences in MitoSOX intensity noted in the different genotypes here cannot be explained by differences in the amount of mitochondrial DNA available for MitoSOX binding. As stated in figure legends, cultures were incubated at $35^{\circ} \mathrm{C}$ in experimental medium containing MitoSOX $(2 \mu \mathrm{M}$ for SCG and $0.1 \mu \mathrm{M}$ for CG neurons) for 10 or $30 \mathrm{~min}$. They were then washed two times with L-15 medium and maintained in L- 15 for microscopy. Unless otherwise stated, the $408 \mathrm{~nm}$ line of the confocal laser was used for excitation (Robinson et al., 2006), and the red photomultiplier channel of the confocal microscope was used for image acquisition.

Unless otherwise stated, for relative determination of $\Delta \psi_{m}$ cultures were exposed in the incubator for $20 \mathrm{~min}$ to experimental culture medium containing $10 \mathrm{nM}$ of the $\Delta \psi_{m}$-dependent dye $\mathrm{TMRM}^{+}$(Kirkland and Franklin, 2007a). They were then washed two times with L-15 medium containing the experimental treatments and $10 \mathrm{nM} \mathrm{TMRM}^{+}$and left in the last wash for microscopy. $\mathrm{TMRM}^{+}$was excited with the $543 \mathrm{~nm}$ laser line of the confocal microscope, and the red photomultiplier channel was used for emission. All microscopy was done at room temperature.

Mitochondria were stained with the mitochondria-specific dye MitoTracker Green by exposing cultures in the incubator for $10 \mathrm{~min}$ to culture medium containing 0.1 $\mu \mathrm{M}$ MitoTracker Green (Kirkland et al., 2007).

The raw pixel intensities of all confocal images for each of the four dyes used were quantified with the region tool of MetaMorph software. The tool was set to cover a circular cytoplasmic area of $60 \mu \mathrm{m}^{2}$. Dye intensities were normalized to the average dye intensity in NGF-maintained sibling cultures of SCG neurons or $25 \mathrm{~mm} \mathrm{KCl} /$ serum-maintained sibling cultures of CG neurons exposed to the dye in the same manner as the experimental cells. Data are shown as fold change from this average.

Immunoblotting and immunocytochemistry. Western blotting was done essentially as described (Kirkland et al., 2002). Cells were scraped from the substrate in PBS, transferred to Eppendorf tubes, washed once with ice-cold PBS containing $1 \mathrm{~mm}$ EDTA, and then homogenized with disposable pestles (Kontes) in a lysis buffer consisting of $25 \%$ glycerol, 60 mм Tris, pH 6.8, 10 mm dithiothreitol, 1 mm EDTA, 0.1\% bromophenol blue, $2 \%$ SDS, and a 1:100 dilution of a protease inhibitor cocktail from Calbiochem or Sigma. After boiling for $5 \mathrm{~min}$, samples were returned to room temperature, spun to pellet debris, and loaded into wells of 10 or $12 \%$ Tris-HCl precast gels (Bio-Rad or Life Gels). After separation by electrophoresis, proteins were transferred onto polyvinylidene difluoride membranes (Millipore), blocked for $1 \mathrm{~h}$ with $2 \%$ GE Healthcare blocking agent in $20 \mathrm{~mm}$ Tris buffered saline (TBS) containing $0.1 \%$ Tween 20 (TBS-T). After several washes with TBS-T, membranes were incubated for $1 \mathrm{~h}$ in blocking buffer containing the primary antibody. The primary antibodies used were as follows: cytochrome $c$ (1:1000 dilution; BD Biosciences Pharmingen), $\beta$ tubulin III (1:1000 dilution; Sigma), Bax (1:500 dilution; Santa Cruz Biotechnology), and SOD1 and SOD2 $(0.2 \mu \mathrm{g} / \mathrm{ml}$ each; StressGen). After several more washes in TBS-T, membranes were incubated for $1 \mathrm{~h}$ at room temperature in blocking buffer containing an HRP-labeled secondary antibody $(1: 1000-1: 4000)$ provided with Advance Western Blotting Detection kits (GE Healthcare). They were next washed with TBS-T and incubated in ECL substrate for 1-3 min. A Fotodyne Foto/Analyst Dual-Light Luminary Workstation running TotalLab software was used for blot documentation and analysis.

Cytochrome $c$ and caspase 3 immunocytochemistry were done essentially as described (Deshmukh and Johnson, 1998; Kirkland and Franklin, 2001; Kirkland et al., 2002). Mouse anti-cytochrome $c$ monoclonal antibodies were from BD Biosciences Pharmingen or Promega. The secondary antibody was an anti-mouse antibody conjugated to Alexa Fluor (1.5-1.7 $\mu \mathrm{g} / \mathrm{ml}$; Invitrogen). Rabbit polyclonal mouse anti-caspase 3 an- tibody was from NeoMarkers. The secondary antibody was an antirabbit polyclonal antibody conjugated to Alexa Fluor (Invitrogen).

Caspase 3 assay. We used the Caspase-Glo 3/7 assay (Promega) to determine caspase 3 activity in cultures of SCG neurons. In this assay, a luminogenic caspase-3/7 substrate is cleaved by either caspase 3 or caspase 7, resulting in release of amino-luciferin, a luciferase substrate. The subsequent reaction of amino-luciferin with luciferase produces light. Intensity of the light is proportional to caspase activity in the sample. Mouse SCG neurons express caspase 3 but not caspase 7 (Wright et al., 2007). Therefore, the assay detects only caspase 3 activity in these cells. Neurons from one ganglion were plated and grown for $6-9 \mathrm{~d}$ in each well of white-walled, clear-bottom 96-well plates. The assay was conducted according to the directions of the manufacturer. Briefly, cultures were washed two times with L-15 medium, followed by addition of $200 \mu \mathrm{l}$ of a 1:1 mixture of Caspase-Glo 3/7 reagent with L-15 medium to lyse cells and start reaction. Plates were shaken, covered, and incubated in the dark at room temperature for $30 \mathrm{~min}$ before recording light intensity. Luminescence intensity was measured with a Spectramax M2 microplate reader (Molecular Devices).

Digitonin permeabilization. Unless otherwise indicated, cultures were treated with intracellular buffer (in mM: $125 \mathrm{KCl}, 2 \mathrm{~K}_{2} \mathrm{HPO}_{4}, 1 \mathrm{MgCl}_{2}, 2$ EGTA, 20 HEPES, pH 7.2, 1 malate, 1 glutamate, and 0.8 ADP) containing digitonin $(5 \mu \mathrm{g} / \mathrm{ml})$ and experimental treatments for $20 \mathrm{~min}$ at $35^{\circ} \mathrm{C}$ in an incubator with a $5 \% \mathrm{CO}_{2}$ atmosphere. Cells were then washed with intracellular buffer lacking digitonin and left in this medium for microscopy.

Quantification of mitochondrial DNA. Genomic and mitochondrial DNA were extracted from SCG cultures using the QuickExtract solution from Epicenter Biotechnologies. Cultures of one-half or one ganglion on coverslips or plastic culture dishes were washed twice with PBS, and the collagen substrate and cells were scraped up from the bottom and transferred to microcentrifuge tubes. All cultures from an individual mouse pup were pooled together. The tubes were centrifuged at $6000 \mathrm{rpm}$ for 60 s to pellet the cells and substrate. The supernatant was removed and the collagen substrate was digested with collagenase $(1 \mathrm{mg} / \mathrm{ml}$ in Leibovitz's L- 15 buffer) at $35^{\circ} \mathrm{C}$ for $20-30 \mathrm{~min}$, until collagen substrate was no longer or barely visible. The cells were pelleted again at $6000 \mathrm{rpm}$ for $60 \mathrm{~s}$ or until solution was clear. The collagenase solution was removed, and the cells were washed twice with PBS. The Quick Extract solution was applied (40 $\mu$ l per ganglion), and the tubes were vortexed for 15-20 s. After another spin, the tubes were incubated at $65^{\circ} \mathrm{C}$ for $6 \mathrm{~min}$, then vortexed again, and boiled for $2 \mathrm{~min}$. The $\mathrm{A}_{260}$ of the samples diluted 1:100 in water was taken, and the amount of DNA used in the real-time PCR reactions was based on this reading.

Real-time PCR reactions were performed with the Qiagen QuantiTect SYBR Green PCR kit. Reactions of $25 \mu l$ were prepared by combining the SYBR Green master mix (two times) with water and primers ( $1 \mu \mathrm{M}$ each, final concentration) and distributing 3.5 reaction volumes worth to individual, labeled tubes. DNA at the appropriate dilution was mixed with an aliquot of the reaction mix, and $25 \mu$ l was transferred to wells of a 96-well plate in triplicate. Water was added to each empty well. The samples were run on a Bio-Rad iCycler machine using the following parameters: cycle 1 (one time), $50.0^{\circ} \mathrm{C}$ for $2 \mathrm{~min}$; cycle 2 (one time), $95.0^{\circ} \mathrm{C}$ for $10 \mathrm{~min}$; cycle 3 ( 40 times), $95.0^{\circ} \mathrm{C}$ for $15 \mathrm{~s}$ (step 1 ) and $60.0^{\circ} \mathrm{C}$ for $1 \mathrm{~min}$ (step 2); cycle 4 (one time), $95.0^{\circ} \mathrm{C}$ for $15 \mathrm{~s}$ (step 1 ), $60.0^{\circ} \mathrm{C}$ for $1 \mathrm{~min}$ (step 2), and $95.0^{\circ} \mathrm{C}$ for $15 \mathrm{~s}$ (step 3). A mouse genomic DNA gene, lipo protein lipase, was used as a reference gene. It was amplified using the following primer pairs: forward, GGA TGG ACG GTA AGA GTG ATT C; reverse, ATC CAA GGG TAG CAG ACA GGT. A mouse mitochondrial gene, nicotinamide adenine dinucleotide dehydrogenase subunit 1, was amplified using the following primer pairs: forward, CCC ATT CGC GTT ATT CTT; reverse, AAG TTG ATC GTA ACG GAA GC. Primers were obtained from Integrated DNA Technologies. Efficiencies for amplification of each gene were determined from dilution curves.

Statistics. Tests for normality of each dataset were done before choosing a statistical analysis method. As appropriate to the data distribution, statistical comparisons were made by Kruskal-Wallis one-way ANOVA on ranks, followed by Dunn's multiple comparisons post hoc test, by the Mann-Whitney rank-sum test, or by the Bonferroni's $t$ test. Statistical 
analysis was done with SigmaPlot 11.1 (Systat Software). All error bars are \pm SEM. Graphs were prepared with SigmaPlot 9.0.1 or 11.1 (Systat Software).

\section{Results}

Bax concentration determined ROS levels in both apoptotic and nonapoptotic neurons

Both mouse SCG and CG neurons in cell culture increase production of ROS after receiving an apoptotic stimulus. We previously demonstrated that genetically lowering Bax protein concentration in these cells suppresses these ROS and that Bax deletion completely prevents the ROS increase (Kirkland et al., 2002). The mitochondrial uncoupler carbonyl cyanide $p$-trifluoromethoxyphenylhydrazone (FCCP) used at a concentration that dissipates the mitochondrial membrane potential $\left(\Delta \psi_{m}\right)$ of SCG neurons also blocks this ROS increase, suggesting that the ROS derive from the mitochondrial electron transport chain (Dugan et al., 1997; Kirkland et al., 2002, 2007b) (supplemental Fig. $3 A, B$, available at www.jneurosci.org as supplemental material). To further explore the effect of Bax on ROS production in both cell types, we used the redox-sensitive dye $\mathrm{CM}-\mathrm{H}_{2}$ DCFDA and the newer redox-sensitive dye MitoSOX Red, in conjunction with confocal microscopy (Royall and Ischiropoulos, 1993; Zhao et al., 2003; Robinson et al., 2006). The former compound becomes fluorescent when oxidized by a number of ROS species. Oxidation of MitoSOX followed by its binding to mitochondrial DNA causes it to become fluorescent. This fluorescence can be used to selectively detect $\mathrm{O}_{2}^{--}$in both of these types of neurons and other cell types (Johnson-Cadwell et al., 2007; Kirkland et al., 2007b). Figure $1 A$ shows phase and confocal micrographs of CM- $\mathrm{H}_{2}$ DCFDA- or MitoSOX-stained SCG or CG neurons induced to undergo apoptosis by NGF withdrawal (SCG) or membrane potential repolarization plus serum withdrawal (CG). Induction of apoptosis led to a significant increase in the fluorescence intensities of MitoSOX and CM- $\mathrm{H}_{2}$ DCFDA in Bax wild-type $\left(\mathrm{bax}^{+/+}\right)$SCG and CG neurons, suggesting increased levels of mitochondrial $\mathrm{O}_{2}^{--}$and other ROS in them (Fig. $1 B$ ) (Kirkland et al., 2002, 2007b). We previously demonstrated that menadione, an $\mathrm{O}_{2}^{--}$generator, increased MitoSOX fluorescence in these cells but that $\mathrm{H}_{2} \mathrm{O}_{2}$ did not (Kirkland et al., 2007b). A membrane-permeant form of SOD, PEG-SOD (Liu et al., 1989), blocked the increased MitoSOX fluorescence in NGFdeprived SCG neurons, providing definitive evidence that it was detecting $\mathrm{O}_{2}^{--}$in these cells (supplemental Fig. $4 A$, available at www.jneurosci.org as supplemental material). PEG-SOD also blocked the concurrent increase of CM- $\mathrm{H}_{2}$ DCFDA fluorescence intensity in NGF-deprived neurons, indicating that the ROS oxidizing this dye derived from dismutation of $\mathrm{O}_{2}^{--}$.

The Bax protein concentration in bax hemizygous $\left(b_{a x}{ }^{+/-}\right)$SCG and CG neurons is approximately half that found in $\mathrm{bax}^{+/+}$neurons, and Bax is absent in both cell types taken from bax ${ }^{-/-}$ animals (Kirkland et al., 2002) (supplemental Fig. 5, available at www.jneurosci.org as supplemental material). MitoSOX and CM- $\mathrm{H}_{2}$ DCFDA fluorescence intensities were lower in $b a x^{+/-}$ SCG and CG neurons receiving apoptotic stimuli than in $b a x^{+/+}$ neurons receiving the same stimuli. There was little or no increase in MitoSOX or CM-H ${ }_{2}$ DCFDA intensities in apoptotic SCG and CG neurons completely lacking Bax. These findings, along with those already reported (Kirkland et al., 2002), suggest that the ROS detected by CM- $\mathrm{H}_{2}$ DCFDA in SCG and CG neurons undergoing apoptosis lie downstream of dismutated $\mathrm{O}_{2}^{--}$derived from the mitochondrial electron transport chain and that Bax has a
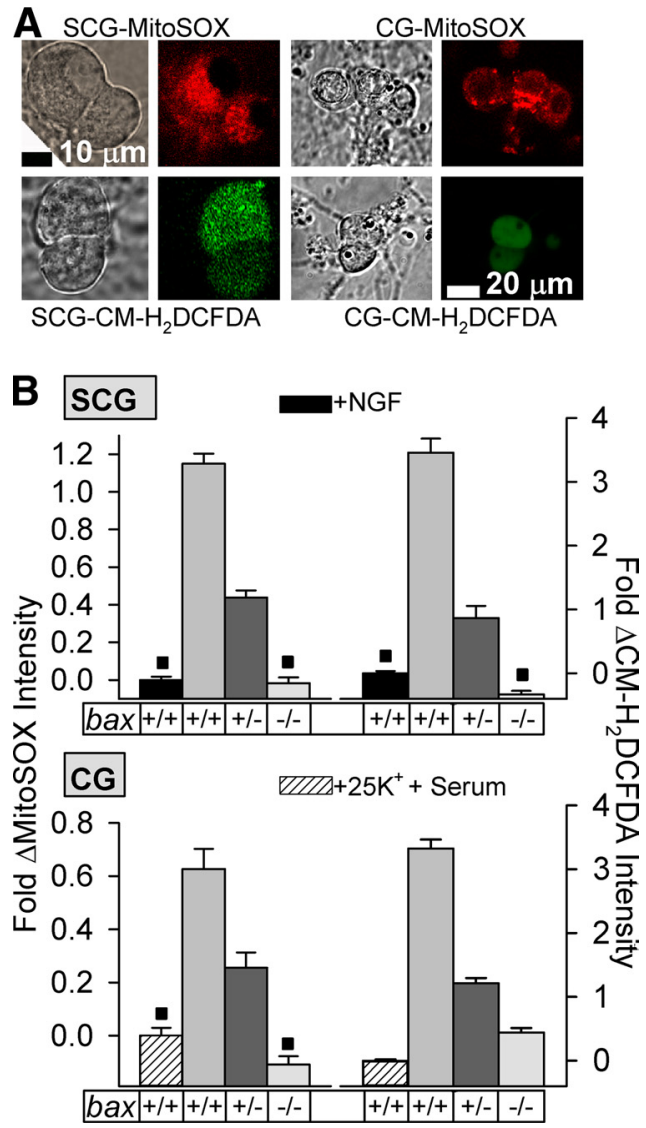

Figure 1. Bax dosage determined rate of $\mathrm{O}_{2}^{--}$and other ROS production in mouse $S C G$ and $C G$ neurons exposed to apoptotic stimuli. $\boldsymbol{A}$, Phase and confocal micrographs of NGF-deprived (24 h) SCG neurons and repolarized/serum-starved (6h) CG neurons exposed to MitoSOX ( $2 \mu \mathrm{M}$ for 10 min for SCG neurons and $0.1 \mu \mathrm{m}$ for 10 min for (G neurons) or to $\mathrm{CM}-\mathrm{H}_{2} \mathrm{DCFDA}$ (10 $\mu \mathrm{m}$ for 20 min for both SCG and (G neurons). Exposure to the dyes in this and subsequent figures was done in the appropriate bicarbonate-buffered culture medium in the incubator. At the end of dye loading, cultures were washed two times with L-15 medium to remove this medium, and cultures were left in the second wash for imaging. Images were immediately acquired by confocal microscopy. Note punctate cytoplasmic staining of MitoSOX, consistent with its demonstrated localization to mitochondria (Johnson-Cadwell et al., 2007; Kirkland et al., 2007b). Repolarization of CG plasma membrane potential and serum withdrawal were accomplished by replacing culture medium containing $25 \mathrm{~mm} \mathrm{KCl}$ and serum with one containing $5 \mathrm{~mm} \mathrm{KCl}$ and no serum. $\boldsymbol{B}$, Genetically decreasing Bax protein concentration reduced both $\mathrm{O}_{2}^{--}$(MitoSOX intensities) and $C M-H_{2} D C F D A$-detected $R O S$ levels in SCG and $C G$ neurons receiving apoptotic stimuli. The apoptotic stimuli and dye-loading protocols were the same as in A. MitoSOX and CM$\mathrm{H}_{2}$ DCFDA dye intensities are normalized to the intensity averages of sibling wild-type cultures not receiving apoptotic stimuli (with NGF from time of plating for SCG neurons and $25 \mathrm{~mm} \mathrm{KCl}$ plus serum for (G neurons). Rate of loading of MitoSOX into these cells during this period is linear (Johnson-Cadwell et al., 2007; Kirkland et al., 2007b). These time points were chosen because they are at or near the peak level of ROS production in these cell types (Kirkland et al., 2002). $n=201-324$ (MitoSOX) and 97-317 (CM-H DCFDA) SCG neurons. $n=124-288$ (MitoSOX) and 262-1009 (CM-H DCFDA) CG neurons. ${ }_{p}>0.01$, not statistically different. All other conditions are different $(p<0.01)$.

major positive influence on mitochondrial $\mathrm{O}_{2}^{--}$production in these cells.

While measuring ROS in control (nonapoptotic) neurons, we noted that Bax concentration also affected basal ROS levels in them. Figure 2 shows that $\mathrm{O}_{2}^{--}$levels, as detected by MitoSOX, were lower in nonapoptotic SCG and CG neurons having genetically reduced concentrations of Bax. The $\mathrm{O}_{2}^{--}$level in neurons with a $b a x^{+/-}$genotype was lower than that in $b a x^{+/+}$neurons but higher than the $\mathrm{O}_{2}^{--}$level in ones with a bax ${ }^{-1-}$ genotype. Similar results were observed with CM- $\mathrm{H}_{2}$ DCFDA-detected ROS 


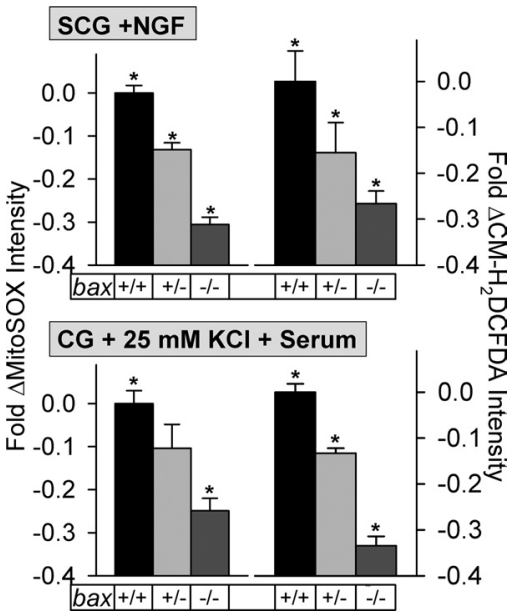

Figure 2. Bax dosage determined rate of production of $\mathrm{O}_{2}^{--}$and other ROS in nonapoptotic mouse SCG and $\mathrm{CG}$ neurons. Levels of $\mathrm{O}_{2}^{--}$(MitoSOX intensities) and other ROS (CM- $\mathrm{H}_{2} \mathrm{DCFDA}$ intensities) were lower in nonapoptotic $b a x^{+/-}$and $b a x^{-/-}$SCG and CG neurons than in $b a x^{+/+}$cells. NGF-maintained SCG neurons were exposed to $2 \mu \mathrm{m}$ MitoSOX for $30 \mathrm{~min}$. CG neurons were maintained in medium containing $25 \mathrm{~mm} \mathrm{KCl}$ and serum and were exposed for 30 min to this medium containing $0.1 \mu \mathrm{m}$ MitoSOX. Uptake of these concentrations of MitoSOX by mitochondria in both types of neurons is linear for at least 30 min (Johnson-Cadwell et al., 2007; Kirkland et al., 2007b). Cultures were washed with L-15 medium at the end of dye loading, and images were immediately acquired by confocal microscopy. MitoSOX and $\mathrm{CM}-\mathrm{H}_{2} \mathrm{DCFDA}$ dye intensities are normalized to the intensity averages of sibling wild-type cultures not receiving apoptotic stimuli (with NGF from time of plating for SCG neurons and $25 \mathrm{~mm} \mathrm{KCl} \mathrm{plus} \mathrm{serum} \mathrm{for}$ (G neurons). $n=162-293$ (MitoSOX) and 118-293 (CM-H DCFDA) SCG neurons. $n=79-287$ (MitoSOX) and 752-2489 (CM-H DCFDA) CG neurons. ${ }^{*} p<0.01$, significantly different from the other conditions within each graph.

in these cells. As with NGF-deprived cells, the fluorescence intensity of both MitoSOX and CM- $\mathrm{H}_{2}$ DCFDA were greatly attenuated in NGF-maintained SCG neurons treated with PEG-SOD (supplemental Fig. 4A, available at www.jneurosci.org as supplemental material). This finding indicates that $\mathrm{O}_{2}^{--}$or $\mathrm{O}_{2}^{--}$-derived ROS oxidized the dyes. Treating NGF-supported $b a x^{-/-}$neurons with PEG-SOD ( $5 \mu \mathrm{g} / \mathrm{ml}$ for $3 \mathrm{~h}$ before and during $30 \mathrm{~min}$ dye loading) did not cause any suppression of MitoSOX intensity compared with untreated bax $x^{-/-}$cells, suggesting that Bax lies upstream of almost all $\mathrm{O}_{2}^{--}$production in these cells $(p>0.1 ; n=$ 131-172).

\section{Decreasing cellular Bax concentration counteracted the pro-oxidant effect of reduced SOD activity}

The $\mathrm{O}_{2}^{--}$produced by the mitochondrial electron transport chain is rapidly converted to $\mathrm{H}_{2} \mathrm{O}_{2}$ by a dismutation reaction catalyzed by SOD enzymes. Metazoan cells express two different types of SOD, a primarily cytoplasmic form (CuZnSOD, also known as SOD1) (McCord and Fridovich, 1969; Halliwell and Gutteridge, 2007; Leitch et al., 2009) and a form found exclusively in the mitochondrial matrix (MnSOD, also known as SOD2) (Keele et al., 1970; McCord et al., 1977; Halliwell and Gutteridge, 2007). The data in Figures 1 and 2 suggest that Bax lies upstream of most, or all, $\mathrm{O}_{2}^{--}$production in both apoptotic and nonapoptotic neurons. However, an accurate assessment of the actual degree to which $\mathrm{Bax}$ contributes to $\mathrm{O}_{2}^{--}$production has to take into account removal of $\mathrm{O}_{2}^{--}$by SOD. High SOD activity could, for example, lead to an underestimation of the degree to which Bax contributes to $\mathrm{O}_{2}^{--}$production by rapidly removing it from cells. As a first step toward investigating $\mathrm{Bax}$-dependent $\mathrm{O}_{2}^{--}$production without SOD contributions, we suppressed SOD1 activity in SCG neurons with diethyldithiocarbamic acid (DETCA). This com-
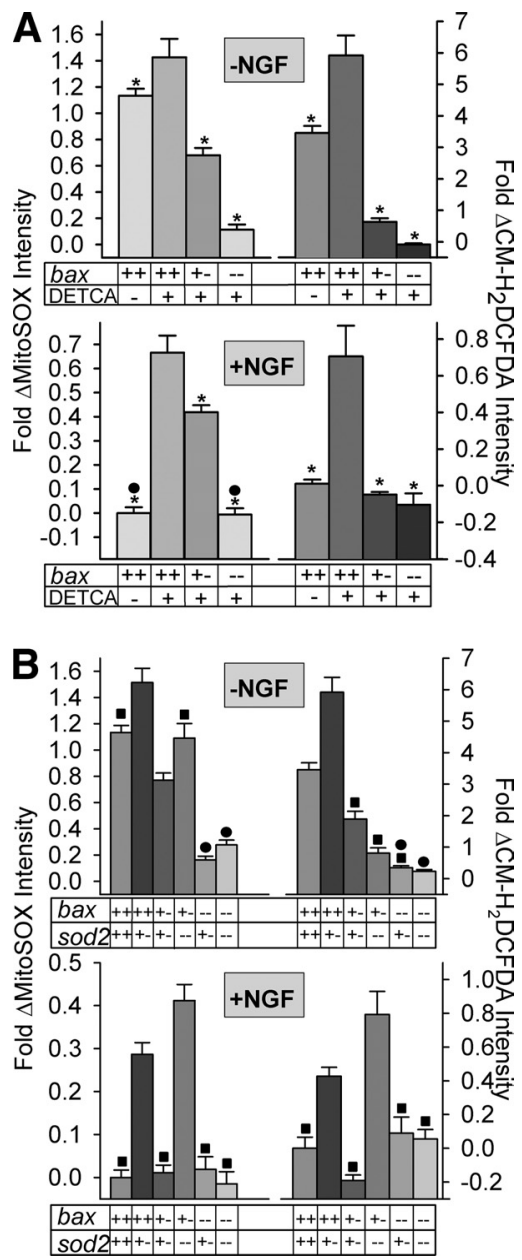

Figure 3. Elevated levels of $\mathrm{O}_{2}^{--}$and other ROS caused by suppression of SOD1 and SOD2 activities in NGF-deprived or -maintained SCG neurons were inhibited by reducing Bax concentration. $A$, The SOD1 antagonist DETCA increased $0_{2}^{--}$(MitoSOX intensities) and other ROS $\left(C M-H_{2} D C F D A\right.$ intensities) in both NGF-deprived and -maintained SCG neurons. This increase was inhibited in cells with genetically reduced Bax concentration and was nearly or completely eliminated in neurons containing no Bax. Cultures were pretreated for $1 \mathrm{~h}$ with DETCA $(100 \mu \mathrm{M})$ before loading with the redox-sensitive dyes. Dye loading was done as described in Materials and Methods and in Figures 1 and 2. DETCA and NGF were included when appropriate in the dye-loading media and in the L- 15 washes and microscopy media. $n=75-592$ neurons. ${ }^{*} p<$ 0.01 , significantly different from DETCA-treated $\mathrm{bax}^{+/+}$cells in each graph. indicate conditions that are not statistically different. $\boldsymbol{B}$, Relative levels of $\mathrm{O}_{2}^{--}$and other ROS in NGF-deprived $(24 \mathrm{~h})$ and -maintained SCG neurons expressing different levels of Bax and SOD2. Reduction of SOD2 concentration increased ROS. This increase was suppressed in neurons with reduced Bax concentrations. $n=105-464$ neurons. $\mathbf{m}, \bullet_{p}>0.01$, conditions that were not statistically different within a graph. All other conditions were different $(p<0.01) . b a x^{+/+} / s_{0} d 2^{-/-}$ neurons were not included in this study because they appeared unhealthy, likely as a result of damage induced by high ROS levels. In both $\boldsymbol{A}$ and $\boldsymbol{B}$, MitoSOX and CM- $\mathrm{H}_{2} \mathrm{DCFDA}$ dye intensities are normalized to the intensity averages of sibling wild-type cultures not receiving apoptotic stimuli (with NGF from time of plating).

pound potently inhibits SOD1 activity by chelating and removing copper from the active sites of the enzyme (Misra, 1979). Figure $3 A$ shows that DETCA significantly increased $\mathrm{O}_{2}^{-}$levels in both NGF-deprived and -maintained $b_{a x}{ }^{+/-}$SCG neurons but had little or no effect on $b a x^{-/-}$cells.

The DETCA results indicate that the production of DETCAsensitive $\mathrm{O}_{2}^{--}$and other ROS in both NGF-deprived and -maintained SCG neurons was almost completely dependent on Bax. However, DETCA is a nonspecific metal chelator that may affect the activity of copper-containing enzymes other than SOD1 (Kober 
et al., 2003; Halliwell and Gutteridge, 2007). It can also bind to other transition metals and has been reported to inhibit an MnSOD (Sevilla et al., 1982). Also, DETCA reduces CM$\mathrm{H}_{2}$ DCFDA loading in these cells (supplemental Fig. 1, available at www.jneurosci.org as supplemental material), likely via binding of the dye to the DETCA thiol. Therefore, although the increased $\mathrm{O}_{2}^{--}$caused by DETCA treatment clearly lay downstream from Bax, we cannot definitively state that it was dismutated by SOD1. There are no specific inhibitors of SOD2. Therefore, to further explore the effects of Bax concentration on mitochondrial $\mathrm{O}_{2}^{\cdot-}$ production in neurons, we bred mice hemizygous for sod 2 with ones hemizygous for bax to generate animals that were hemizygous for both bax and sod2. Mice that have genetically reduced levels of SOD2 can serve as models of endogenous oxidative stress. The offspring resulting from breeding the doubly hemizygous animals to each other included mice in which a partial or complete loss of SOD2 was accompanied by a partial or complete loss of Bax. There was no effect of reducing sod 2 gene dosage on Bax protein concentration, and reducing bax gene dosage had no effect on expression of SOD2. Additionally, altering sod2 and bax gene dosages had no effect on expression of SOD1 protein (CG neurons) (supplemental Fig. 5A-C, available at www.jneurosci. org as supplemental material). The mitochondria in the cells of these animals have considerably $\left(\operatorname{sod} 2^{+/-}\right)$or greatly $\left(\operatorname{sod} 2^{-/-}\right)$ reduced ability to convert mitochondrial-produced $\mathrm{O}_{2}^{--}$to $\mathrm{H}_{2} \mathrm{O}_{2}$ (Melov et al., 1999; Melov, 2004). $\mathrm{O}_{2}^{--}$and other ROS levels in SCG neurons having different bax/sod2 genotypes were determined by confocal imaging of neurons loaded with MitoSOX or $\mathrm{CM}-\mathrm{H}_{2}$ DCFDA. Decreasing sod2 gene dosage caused an increase of $\mathrm{O}_{2}^{--}$and other ROS in both NGF-deprived and -maintained $b a x^{+/+}$SCG neurons (Fig. 3B). This increase was greatly reduced or eliminated in neurons having $b a x^{+/-}$or $b a x^{-/-}$genotypes. Decreasing sod2 gene dosage also caused an increase of $\mathrm{O}_{2}^{--}$and other ROS in nonapoptotic and apoptotic bax ${ }^{+/+}$CG neurons (Fig. $4 A, B$ ). As with SCG neurons, CG neurons that had genetically reduced concentrations of Bax and SOD2 had lower levels of $\mathrm{O}_{2}^{--}$and other ROS than did $b a x^{+/+}$CG neurons with reduced SOD2 concentrations.

The MitoSOX data indicate that the mitochondria of many neurons with inhibited SOD1 activity or reduced SOD2 expression had elevated $\mathrm{O}_{2}^{--}$levels, presumably as a result of reduced dismutation of $\mathrm{O}_{2}^{--}$to $\mathrm{H}_{2} \mathrm{O}_{2}$. It is unclear why CM- $\mathrm{H}_{2}$ DCFDA also showed increased oxidation in these neurons because it appears to be primarily oxidized by ROS downstream of $\mathrm{O}_{2}^{--}$and is relatively insensitive to oxidation by $\mathrm{O}_{2}^{--}$itself. It is possible that a longer dwell time for $\mathrm{O}_{2}^{--}$in cells with reduced SOD activity allowed increased opportunities for it to oxidize the dye or that pathways other than the SOD pathways converted $\mathrm{O}_{2}^{--}$to ROS that can oxidize $\mathrm{CM}-\mathrm{H}_{2}$ DCFDA (Halliwell and Gutteridge, 2007). Regardless of the answer, the combined data indicate that most of the mitochondrial-derived $\mathrm{O}_{2}^{-}$and other ROS produced in both apoptotic and nonapoptotic SCG and CG neurons is Bax dependent.

It should be noted that the higher ROS levels in "nonapoptotic" cultures containing more Bax than in ones with less Bax cannot be explained by high ROS levels in a small number of apoptotic cells in those cultures. Wild-type NGF-supported SCG and high potassium/serum-supported CG cultures of the age used in this study show no detectable apoptotic death (O'Hare et al., 2000; Deshmukh et al., 2002; Vaughn and Deshmukh, 2007). Supplemental Figure $4 B$ (available at www.jneurosci.org as supplemental material) shows that there were no cells in either wildtype nonapoptotic cultures or in nonapoptotic cultures with

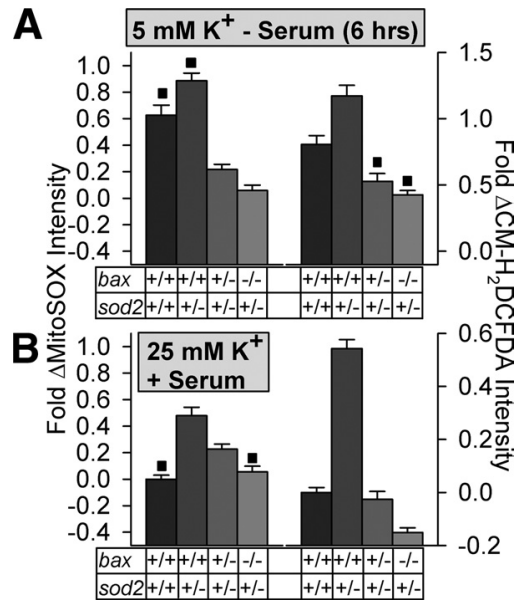

Figure 4. Production of $\mathrm{O}_{2}^{--}$and other ROS in apoptotic and nonapoptotic C $G$ neurons were influenced by both Bax and SOD2 levels. $A$, Relative $0_{2}^{--}$levels (MitoSOX intensities) and other ROS (CM- $\mathrm{H}_{2}$ DCFDA intensities) in apoptotic C $G$ neurons expressing different concentrations of Bax and SOD2. Medium was replaced with one lacking serum and containing $5 \mathrm{~mm} \mathrm{KCl} \mathrm{for} 6 \mathrm{~h}$ to induce apoptosis. $\boldsymbol{B}$, Relative $\mathrm{O}_{2}^{--}$and other ROS levels in nonapoptotic $\mathrm{CG}_{\mathrm{C}}$ neurons expressing different concentrations of Bax and SOD2. Medium contained serum and $25 \mathrm{~mm} \mathrm{KCl}$. Neurons were exposed to redox-sensitive dyes as described for CG neurons in Figures 1 and 2. MitoSOX and $\mathrm{CM}-\mathrm{H}_{2} \mathrm{DCFDA}$ dye intensities are normalized to the intensity averages of sibling wild-type cultures not receiving apoptotic stimuli with $25 \mathrm{~mm} \mathrm{KCl}$ plus serum. $\boldsymbol{\nabla}_{p}>0.01$, conditions that are not statistically different within individual graphs. All other conditions within the graphs are different $\left(p<0.01\right.$ ). Animals with an sod $2^{-/-}$genotype did not live long enough to allow CG cultures to be established from them. $n=125-993$ neurons.

varying genotypes that had the high ROS levels found in apoptotic cells. Rather, the lower average ROS levels in nonapoptotic neurons having reduced levels of Bax resulted from a decrease in basal ROS levels.

\section{Caspases have a role in $\mathrm{ROS}$ production}

To pursue mechanisms underlying the effects of $\mathrm{Bax}$ on $\mathrm{O}_{2}^{--}$production, we chose to use SCG rather than CG neurons because the role of Bax in ROS production is better characterized in them. There are several possible means by which Bax could influence mitochondrial $\mathrm{O}_{2}^{--}$production in apoptotic and nonapoptotic cells. First, Bax-induced depletion of cytochrome $c$ from the electron transport chain could inhibit the flow of electrons through the respiratory complexes (Cai and Jones, 1998). Such inhibition could increase electron stalling upstream of cytochrome $c$ in the chain and cause more electrons to leak to $\mathrm{O}_{2}$ to produce $\mathrm{O}_{2}^{--}$. This mechanism can be discounted in nonapoptotic cells because they retain cytochrome $c$ within the mitochondrial intermembrane space. It can also probably be discounted in apoptotic neurons because we showed that ROS increases well before a substantial portion of cytochrome $c$ is released from mitochondria, at least in SCG neurons (Kirkland et al., 2002). Second, bax $x^{+/+}$neurons might produce more $\mathrm{O}_{2}^{--}$than do bax $x^{+/-}$or $b_{a x}{ }^{-1-}$ cells because they have greater mitochondrial mass (Karbowski and Youle, 2003; Karbowski et al., 2006). However, Figure $5 A$ shows that NGF-supported SCG neurons having each of the three bax genotypes had similar levels of cytochrome $c$, suggesting that they had similar mitochondrial masses. The mitochondriaspecific dye MitoTracker Green can be used to obtain a comparative estimate of mitochondrial density/volume in different cells. Figure $5 B$ shows that there were no differences in MitoTracker Green staining in $b a x^{+/+} / \operatorname{sod} 2^{+/+}, b a x^{-/-} / \operatorname{sod} 2^{+/+}$, and $b a x^{-/}$ ${ }^{-} /$sod $2^{-1+}$ cells. This finding indicates equivalent mitochondrial volume in these representative genotypes. The findings shown in 
A
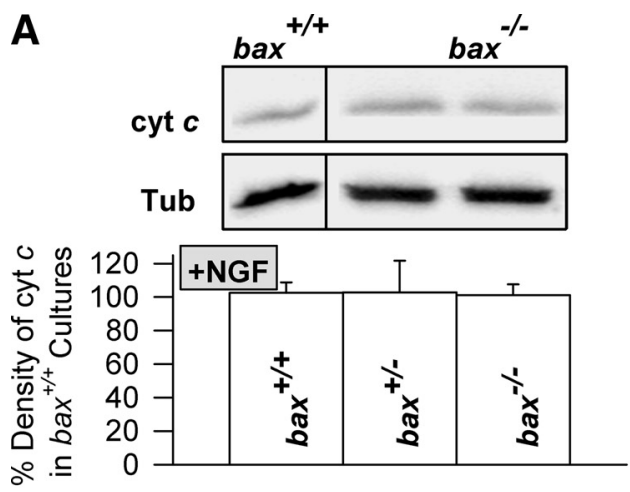

B

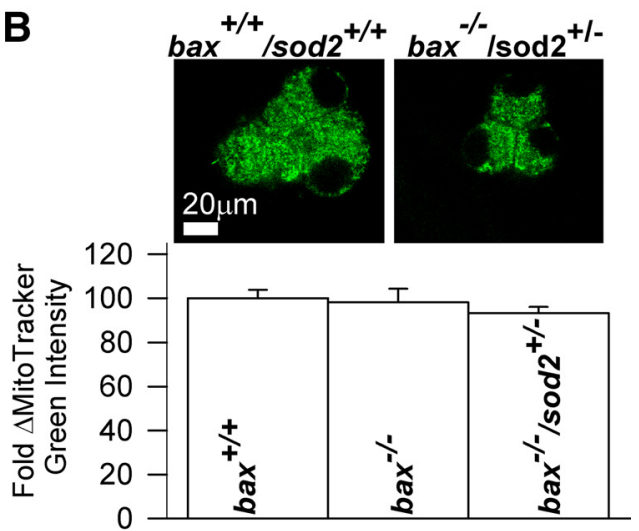

C

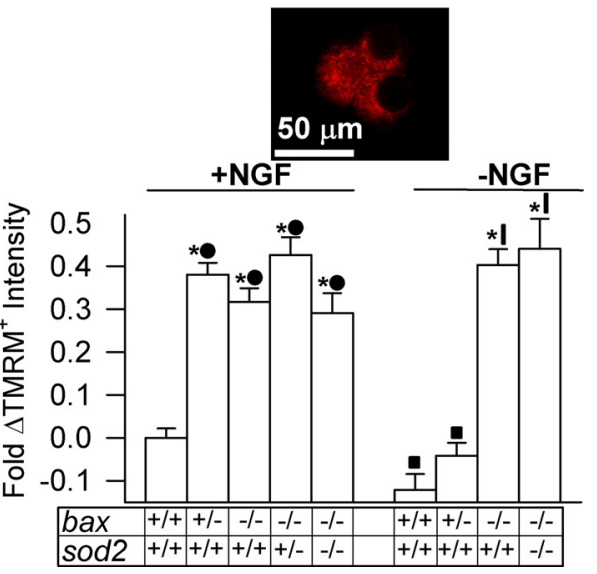

Figure 5. Alterations in mitochondrial mass or $\Delta \psi_{m}$ could not explain the effect of Bax concentration on $0_{2}^{--}$levels in SCG neurons. $A$, NGF-maintained neurons with each of the three bax genotypes expressed identical levels ( $p>0.1$ ) of cytochrome $c$, suggesting that they had equal mitochondrial mass. Immunoblots at the top show cytochrome c (cyt c) and $\beta$ tubulin III (Tub) from the same lanes of a gel. The $b a x^{+/+}$and $b a x^{-/-}$blots are from the same gel. Bottom shows quantification of cytochrome $c$ immunoblot band density for cultures having each of the three bax genotypes. Cytochrome $c$ concentration (density of immunoblot bands) was normalized to amount of $\beta$ tubulin III in the same lanes of the gels. $n=5-23$ cultures. $\boldsymbol{B}$, Top, somas of NGF-maintained $b a x^{+/+}$and $b a x^{-/-}$SCG neurons stained with the mitochondria-specific dye MitoTracker Green. Graphs show quantification of MitoTracker Green staining in the somas of NGF-maintained SCG neurons having the indicated genotypes. There were no significant differences in the somatic staining intensities of the three genotypes ( $p>$ 0.1). These data denote that alterations in either bax or sod2 gene dosage did not affect mitochondrial mass in these cells. Data were normalized to the MitoTracker Green intensity measured in wild-type cells. $n=34-104$ neurons. $C$, Reducing Bax protein levels increased $\Delta \psi_{m}$. Top, Soma of NGF-supported $b a x^{+/+} /$sod2 $2^{+/+}$SCG neurons loaded with the $\Delta \psi_{m}$ indicator $\mathrm{TMRM}^{+}$(10 $\mathrm{nm}$ for $20 \mathrm{~min}$ ). Note punctate mitochondrial staining. Bottom, Quantification of TMRM $^{+}$staining in neurons having the indicated bax and sod2 genotypes. NGF-withdrawal decreased $\Delta \psi_{m}\left(\right.$ TMRM $^{+}$staining) in bax ${ }^{+/+}$cells. Both NGF-supported and -deprived neurons from $b a x^{+/-}$and $b a x^{-/-}$mice had hyperpolarized $\Delta \psi_{m}$ compared with neurons from $\mathrm{bax}^{+/+}$mice receiving the same treatment. Reducing sod 2 gene dosage had no effect on this supplemental Figure $5 A$ demonstrate that $b_{a x}{ }^{+/+}$and $b a x^{-/-}$CG neurons express the same level of SOD2 protein, suggesting that these neurons also have equivalent mitochondrial volumes. A third possibility is that Bax influences $\Delta \psi_{m}$. Higher $\Delta \psi_{m}$ (more hyperpolarized) can increase electron leakage from the chain and elevate $\mathrm{O}_{2}^{-}$production (Starkov et al., 2002). To determine whether Bax affects $\Delta \psi_{m}$, we used the $\Delta \psi_{m}$-sensitive dye $\mathrm{TMRM}^{+}$(Nicholls and Budd, 2000; Nicholls and Ward, 2000; Nicholls and Ferguson, 2002). Figure 5C shows that $\Delta \psi_{m}$ was actually higher in NGF-supported or -deprived SCG $b_{a x} x^{+/-}$or $b_{a x} x^{-/-}$neurons than in $b_{a x}^{+/+}$cells, the opposite of what would be expected if Bax increased $\mathrm{O}_{2}^{--}$production via an effect on $\Delta \psi_{m}$. The hyperpolarization caused by reduced bax gene dosage was not affected in cells having lower sod 2 gene dosages. The mitochondrial complex I inhibitor rotenone and the complex III inhibitor antimycin A can increase mitochondrial ROS production by increasing leakage of electrons from the electron transport chain (Fiskum et al., 2000). To determine whether bax genotype affects the ability of these compounds to increase ROS production in SCG neurons, we exposed $b a x^{+/+}$and $b a x^{-/-}$cells to either rotenone or antimycin A and determined ROS production with MitoSOX or CM- $\mathrm{H}_{2}$ DCFDA. Supplemental Figure 6 (available at www.jneurosci.org as supplemental material) shows that neurons having either $b a x^{+/+}$or $b a x^{-/-}$genotypes had equivalent abilities to increase ROS when exposed to these compounds. Therefore, although Bax deletion reduced both basal and apoptotic ROS levels in SCG neurons, it did not alter ROS production by mitochondria when the electron transport chain was artificially blocked.

A fourth possibility for how Bax could influence mitochondrial ROS production is via activation of caspases. Most Bax resides in the cytoplasm of nonapoptotic cells. It inserts into the outer mitochondrial membrane (OMM) during apoptosis. This insertion causes permeabilization of the OMM and redistribution of cytochrome $c$ into the cytoplasm in which it causes activation of caspases and subsequent cell death by inducing formation of the apoptosome (Li et al., 1997; Goldstein et al., 2000; Du et al., 2000; Adrain and Martin, 2001; Li et al., 2001; Suzuki et al., 2001; Danial and Korsmeyer, 2004; LuckenArdjomande et al., 2008; Qian et al., 2008). Bax deletion blocks the apoptotic death of NGF-deprived SCG neurons and repolarized/serum-starved CG neurons (Deckwerth et al., 1996; Miller et al., 1997). Permeabilization of the OMM during the apoptotic death of at least some cell types allows activated cytosolic caspase 3 to gain access to the mitochondrial intermembrane space in which it cleaves specific respiratory complex subunits, dissipating $\Delta \psi_{m}$ and increasing mitochondrial ROS production (Ricci et al., 2003, 2004).

The ROS increase that occurs in SCG, CG, and other types of neurons receiving apoptotic stimuli is greatly attenuated by caspase inhibitors, suggesting that some of the elevated ROS is caused by similar cleavage of respiratory complex subunits in those cells (Tan et al., 1998; Kirkland et al., 2001, 2002, 2007b). Figure $6 \mathrm{~A}$ provides evidence that caspase cleavage of respiratory complexes may be responsible for at least some of the increased ROS during the apoptotic death of NGF-deprived SCG neurons.

$\leftarrow$

hyperpolarization. TMRM ${ }^{+}$dye intensities in SCG neurons are normalized to the intensity averages of wild-type cultures maintained in medium containing NGF from the time of plating. ${ }^{*} p<0.01$, significantly different from wild-type. ${ }^{\square} p>0.01$, conditions that were not significantly different from each other. 
A
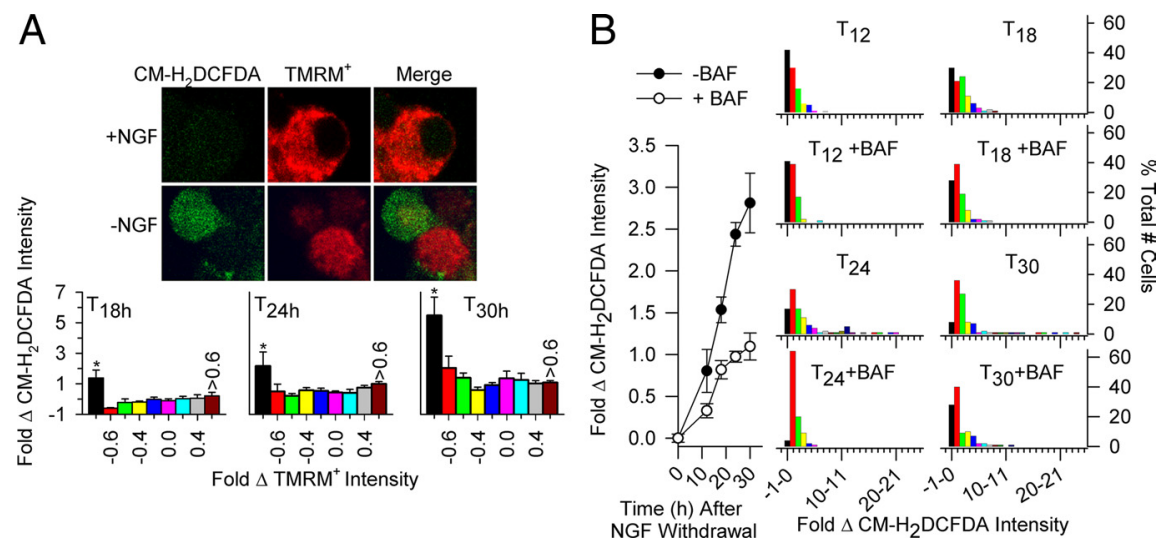

Figure 6. The highest ROS levels in NGF-deprived bax ${ }^{+/+}$SCG neurons were found in cells having the lowest $\Delta \psi_{m}$ and were suppressed by caspase inhibition. $A$, Relative ROS and $\Delta \psi_{m}$ levels (CM- ${ }_{2} D C F D A$ intensities and TMRM ${ }^{+}$intensities, respectively) could be determined in single mouse SCG neurons in cell culture. Top, Confocal micrographs of NGF-maintained or -deprived $b x^{+/+}$SCG neuronal somas double labeled with $\mathrm{CM}_{-} \mathrm{H}_{2}$ DCFDA (green, left) and TMRM ${ }^{+}$(red, middle). Right panels show merged $\mathrm{CM}_{-} \mathrm{H}_{2} \mathrm{DCFDA}$ and $\mathrm{TMRM}^{+}$staining. Higher TMRM ${ }^{+}$intensity indicates more hyperpolarized $\Delta \psi_{m}$, whereas higher $\mathrm{CM}-\mathrm{H}_{2} \mathrm{DCFDA}$ intensity indicates elevated ROS. The NGF-maintained cell exhibits intense punctate TMRM ${ }^{+}$staining and diffuse,

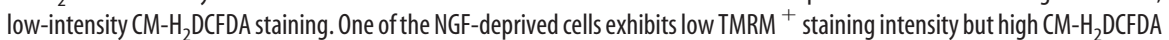
intensity, indicating that this cell had elevated ROS levels but depolarized $\Delta \psi_{m}$. Bottom, ROS levels (CM- $\mathrm{H}_{2} \mathrm{DCFDA}$ intensity) in

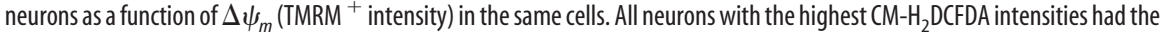
lowest TMRM ${ }^{+}$intensities. Neurons were deprived of NGF for $18-30 \mathrm{~h}$ before loading with dyes in culture medium in the incubator (10 nM TMRM ${ }^{+}$and $10 \mu \mathrm{M}$ CM-H DCFDA for $20 \mathrm{~min}$ ). This was followed by washing two times with L-15 medium containing $10 \mathrm{nM} \mathrm{TMRM}^{+}$; cells were left in the last wash for microscopy. Changes in dye intensity are shown as change from average values in NGF-maintained cultures. Bins are divided into 0.2 -fold change of TMRM ${ }^{+}$intensities. The amplitude of each bin represents the average $\mathrm{CM}-\mathrm{H}_{2} \mathrm{DCFDA}$ intensity of neurons within a particular range of TMRM ${ }^{+}$intensities. ${ }^{*}$ indicate significantly different from the other bins within the individual graphs. $p<0.01 ; n=137-263$ neurons. $B$, The broad-spectrum caspase inhibitor BAF $(50 \mu \mathrm{m})$ attenuated the elevated ROS levels after NGF withdrawal. Left, BAF decreased the average ROS (CM$\mathrm{H}_{2}$ DCFDA intensity) after NGF withdrawal. Right, The plots show that the average decrease in ROS caused by BAF in NGF-deprived cells resulted from both a decrease in the number of NGF-deprived neurons having the greatest elevation of ROS and a decrease of ROS in many other neurons as well. Bins represent percentage of total number of cells $(100 \%)$ having the indicated average increase in $\mathrm{CM}-\mathrm{H}_{2} \mathrm{DCFDA}$ intensity at the indicated times. Each bin represents a onefold intensity change (e.g., $10-11$ is the percentage of total neurons showing a 10 -fold to 11 -fold change of $\left(\mathrm{H}_{-}-\mathrm{H}_{2} \mathrm{DCFDA}\right.$ intensities). BAF treatment began at the time of deprivation. $n=112-372$ cells.

Cultures of NGF-deprived $b_{a x}{ }^{+/+}$neurons were double labeled with CM- $\mathrm{H}_{2}$ DCFDA and TMRM ${ }^{+}$. Figure $5 C$ shows that, by $24 \mathrm{~h}$ after NGF withdrawal, average $\mathrm{TMRM}^{+}$intensity had decreased below control intensity measured in NGF-replete bax ${ }^{+/+}$cells. Conversely, average $\mathrm{CM}-\mathrm{H}_{2} \mathrm{DCFDA}$ intensity increased throughout the period (Fig. 1A). Figure 6A shows a plot of the CM$\mathrm{H}_{2}$ DCFDA intensities in neurons as a function of the TMRM ${ }^{+}$ intensities measured in the same neurons at various times after NGF withdrawal. There was a wide range of CM- $\mathrm{H}_{2}$ DCFDA intensities at most $\mathrm{TMRM}^{+}$intensities. However, although CM$\mathrm{H}_{2}$ DCFDA intensities varied at any given TMRM ${ }^{+}$intensity, the highest $\mathrm{CM}-\mathrm{H}_{2} \mathrm{DCFDA}$ intensities occurred only in cells with the lowest TMRM ${ }^{+}$intensities. By $18 \mathrm{~h}$ and later times after NGF withdrawal, all neurons with the highest ROS levels had the lowest (depolarized) $\Delta \psi_{m}$. Treatment of NGF-deprived cultures with BAF reduced the average increase in $\mathrm{CM}-\mathrm{H}_{2}$ DCFDA intensities at all times after NGF withdrawal (Fig. 6B) (Deshmukh et al., 1996; Kirkland and Franklin, 2001; Kirkland et al., 2002). Investigation of the effect of BAF on ROS in single cells (Fig. 6B) revealed that this inhibitor attenuated increased ROS caused by NGF deprivation and blocked the highest ROS levels associated with the lowest $\Delta \psi_{m}$. The ROS measured after NGF deprivation was potently suppressed by treatment with FCCP at a concentration that maximally reduces $\Delta \psi_{m}$ (supplemental Fig. $3 A, B$, available at www.jneurosci.org as supplemental material), suggesting that they derive from the mitochondrial electron transport chain. The large decrease in $\Delta \psi_{m}$ associated with the cells having the highest ROS levels suggests the possibility that respiratory complexes may have been damaged and that electrons were leaking from the transport chain to produce $\mathrm{O}_{2}^{\cdot-}$ rather than traveling through the chain to pump proteins into the intermembrane space. The ability of FCCP to suppress ROS suggests that the low (partially depolarized) $\Delta \psi_{m}$ associated with the cells having the highest ROS levels was nevertheless necessary for ROS production. A role for caspase activity is supported by the BAF suppression of the ROS increase and BAF prevention of $\Delta \psi_{m}$ loss.

Recent reports demonstrate that nonapoptotic cells can have constitutive lowlevel caspase activity and that caspases have physiological functions beyond their role in apoptotic cell death (Yousefi et al., 2003; He et al., 2004; Nhan et al., 2006; Gdynia et al., 2007; Li et al., 2010). Because of the dependency of $\mathrm{O}_{2}^{--}$production on Bax in both apoptotic and nonapoptotic SCG and CG (Desagher et al., 1999) neurons and because there is a considerable amount of Bax associated with the mitochondria of both nonapoptotic cell types (Desagher et al., 1999; Putcha et al., 2000), we speculated that caspases might mediate the pro-oxidant effect of Bax in nonapoptotic neurons. We hypothesized that the Bax associated with mitochondria in nonapoptotic neurons causes enough permeabilization of the OMM to allow active caspases access into the mitochondrial intermembrane space in which they cause a continuous, low-level degradation of respiratory complexes, thereby increasing $\mathrm{O}_{2}^{--}$production. Because of its importance in the apoptotic death of NGF-deprived SCG neurons and because of its role in increasing mitochondrial ROS production during apoptosis in other cell types, we explored a possible role for caspase 3 in ROS production in nonapoptotic SCG neurons (Ricci et al., 2003, 2004; Wright et al., 2007). Figure 7A shows that there was basal caspase 3 activity in wild-type NGFsupported SCG neurons and that it was suppressed by BAF. Increased caspase 3 activity after NGF withdrawal was also potently suppressed by BAF. Both NGF-supported $b a x^{+/-}$and $b a x^{-/-}$ neurons had BAF-suppressible caspase 3 activity levels comparable with those in wild-type cells. This finding indicates that the Bax level did not directly affect basal caspase 3 activity. Should a slow, continuous degradation of respiratory complexes by caspases underlie basal mitochondrial $\mathrm{O}_{2}^{--}$production in NGFsupported cells, then long-term application of BAF should suppress basal $\mathrm{O}_{2}^{-}$levels in them. Figure $7 B$ shows that BAF did not suppress $\mathrm{O}_{2}^{--}$levels in NGF-supported $b a x^{+/+}$cells when applied acutely; however, it did suppress mitochondrial $\mathrm{O}_{2}^{-}$production in these cells when they were exposed to it for $6 \mathrm{~h}$ (Fig. $7 B$ ). These data are consistent with basal caspase activity being involved in the generation of $\mathrm{O}_{2}^{--}$in nonapoptotic SCG neurons.

To explore a possible role for caspases in Bax-mediated ROS production in nonapoptotic SCG neurons, we used digitonin to introduce active caspase 3 or a Bcl-2 homology 3 (BH3)containing protein (a truncated form of Bax) into their cyto- 

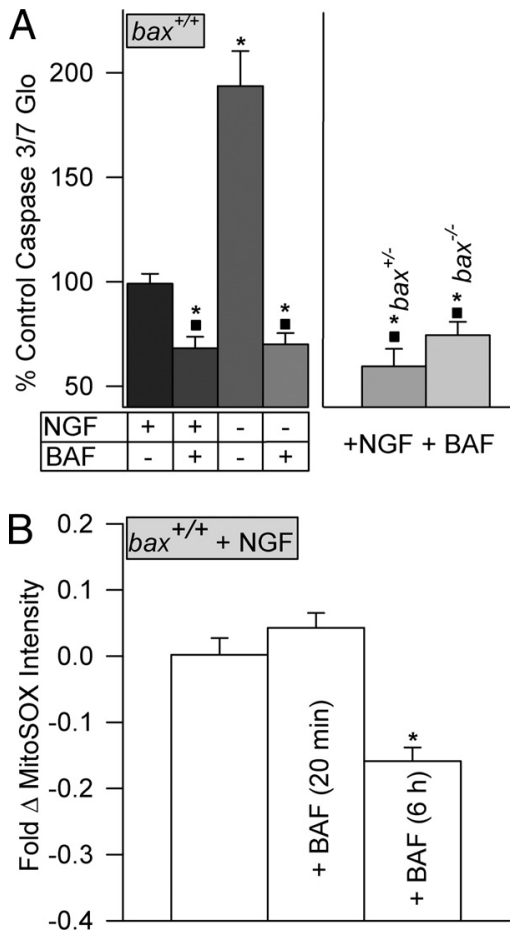

Figure 7. BAF suppressed caspase 3 activity and $0_{2}^{--}$levels in both apoptotic and nonapoptotic SCG neurons. $A$, Caspase 3 activity in SCG neurons determined by the Caspase $\mathrm{Gl} 03 / 7$ assay. Left, BAF ( $50 \mu \mathrm{m}$ for $24 \mathrm{~h}$ ) potently suppressed caspase 3 activity in NGF-supported or -deprived (24 h) $\mathrm{bax}^{+/+}$neurons. Data were normalized to the average activity measured in the NGFsupported cells (control) without BAF treatment. Right, BAF caused a similar level of suppression of caspase 3 activity in NGF-supported cells with $b a x^{+/-}$and $b a x^{-/-}$genotypes, suggesting that all three bax genotypes had equivalent levels of active caspase 3 . Data were normalized to the activity in NGF-supported sibling cultures of the same genotype without BAF. $n=6-12$ cultures. ${ }_{p}>0.01$, conditions that are not statistically different. ${ }^{*} p<0.01$, significant difference from NGF-supported $b a x^{+/+}$neurons. There were no statistical differences in the basal caspase activities of the three bax genotypes ( $p>0.01$; all had the same plating density). $\boldsymbol{B}$, Long-term, but not acute, BAF (50 $\mu \mathrm{M}$ ) treatment suppressed MitoSOX staining in NGF-supported $b a x^{+/+} S C G$ neurons. MitoSOX intensities are normalized to the intensity averages of sibling wild-type cultures not receiving apoptotic stimuli (with NGF from time of plating). $n=153-233$ neurons. ${ }^{*} p<0.01$ compared with NGF-supported $b a x^{+/+}$ cells with no BAF.

plasm (Fiskum et al., 1980, 2000). Digitonin dissolves cholesterol from the plasma membrane, permeabilizing it and allowing large molecules to be introduced into the cytoplasm of cells. Because mitochondria and intracellular membranes contain little cholesterol, optimal concentrations of digitonin can permeabilize the plasma membrane without damaging mitochondria and other cellular organelles. Figure $8 \mathrm{~A}$ shows that treatment of NGFsupported SCG neurons with an intracellular buffer containing 5 $\mu \mathrm{g} / \mathrm{ml}$ digitonin allowed entry of $70 \mathrm{kDa}$ rhodamine-labeled dextran into the cytoplasm of most SCG neurons within $20 \mathrm{~min}$ of exposure. Digitonin permeabilization of cells in buffer containing complex I substrates and ADP (see Materials and Methods) had little effect on $\Delta \psi_{m}$ (Fig. $8 B$ ), indicating that the IMM was not disrupted and that the mitochondria remained energized at a level nearly equivalent to that in the nonpermeabilized cells. The permeabilization also did not cause release of cytochrome $c$ from the intermembrane space, indicating that the OMM remained intact as well (Fig. 8C).

Figure $9 A$ shows that introduction of active caspase $3(0.5 \mathrm{~nm}$ but not $0.1 \mathrm{nM}$ ) into the cytoplasm of NGF-supported $\mathrm{bax}^{+/+}$ SCG neurons caused an $\sim 0.9$-fold increase in MitoSOX intensity, indicating that it augmented $\mathrm{O}_{2}^{--}$production. This increase
A
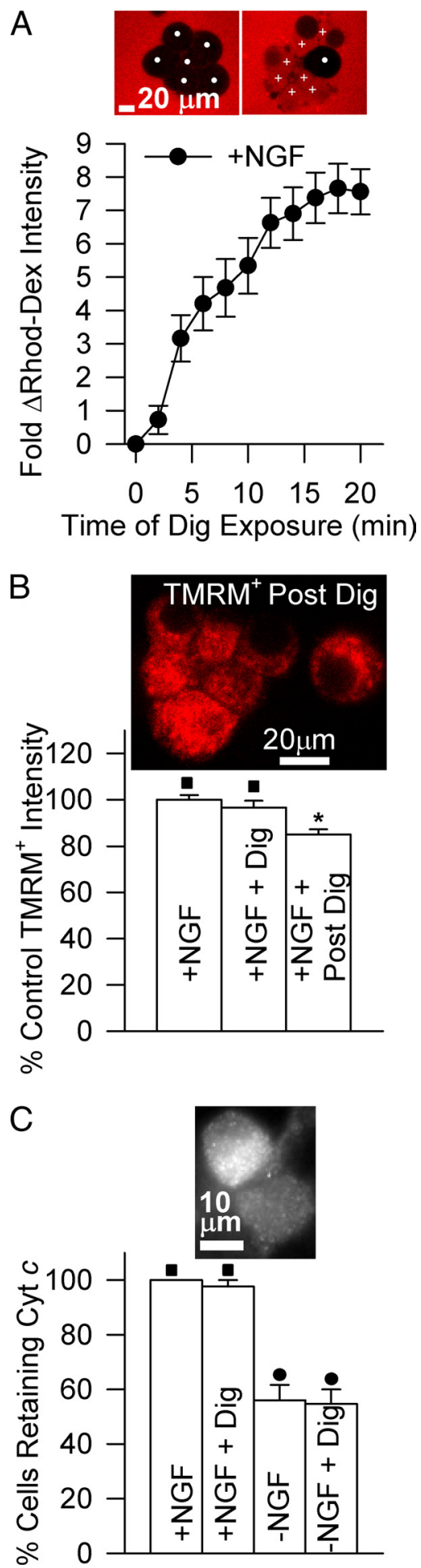

Figure 8. Digitonin permeabilized the plasma membrane of $S C G$ neurons with little effect on mitochondrial physiology. $A$, Treatment of SCG neurons in culture with digitonin $(5 \mu \mathrm{g} / \mathrm{ml})$ allowed large molecules to enter the cytoplasm. Top left, Confocal images of NGF-maintained neuronal somas exposed for $20 \mathrm{~min}$ to intracellular medium containing polydextran $(70 \mathrm{kDa})$ labeled with the fluorescent dye rhodamine [100 $\mu \mathrm{g} / \mathrm{ml}$ dextran/rhodamine (Rhod-Dex)]. No rhodamine labeling occurred in the six neuronal somas shown (-), indicating that the dextran/ dye molecules could not cross the plasma membrane. Top right, Confocal images of eight NGF-maintained neuronal somas exposed for 20 min to intracellular media containing rhodamine-labeled polydextran (70 kDa; $100 \mu \mathrm{g} / \mathrm{ml})$ and digitonin $(5 \mu \mathrm{g} / \mathrm{ml})$. Rhodamine labeling occurred in seven $(+)$ of the eight somas, indicating that the dextran/dye combination had crossed the plasma membrane. Bottom, Time course of increase in somatic rhodamine/ dextran (70 kDa; $100 \mu \mathrm{g} / \mathrm{ml})$ intensity in NGF-maintained neurons exposed to digitonin 
was completely suppressible by BAF and FCCP, suggesting that it was mediated by the caspase 3 activity and that the $\mathrm{O}_{2}^{--}$detected by the MitoSOX derived from the mitochondrial electron transport chain. Addition of a BH3-containing protein (Bax, 38-171 amino acids; lacking both the $\mathrm{N}$-terminal signal sequence and the C-terminal transmembrane domain) (Priault et al., 2003; Valentijn et al., 2008) caused an increase in MitoSOX intensity equivalent to that of the caspase 3 alone. This increase was both BAF and FCCP suppressible as well, suggesting that caspase activity was required for the $\mathrm{O}_{2}^{--}$rise and that the $\mathrm{O}_{2}^{--}$detected derived from the electron transport chain. Immunostaining for cytochrome $c$ showed that addition of the truncated Bax caused clear release of cytochrome $c$ in $83 \pm 2 \%$ of $b a x^{+/+}$-permeabilized neurons but only in $25 \pm 2 \%$ of $b a x^{-/-}$-permeabilized cells (supplemental Fig. 7, available at www.jneurosci.org as supplemental material). Immunostaining for caspase 3 revealed that all digitoninpermeabilized cells retained some caspase 3 in their cytoplasm (Fig. 9A). Addition of active caspase 3 and Bax together caused an additional increase in MitoSOX intensity $(p<0.01$ compared with caspase 3 or Bax addition alone). The same set of experiments was done with digitonin-permeabilized and NGFsupported SCG neurons from $b a x^{-1-}$ animals (Fig. 9B). Addition of caspase 3 had no significant effect on MitoSOX intensity in these cells $(p>0.01)$. The truncated Bax alone or truncated Bax and caspase 3 added together did not significantly increase MitoSOX intensity.

Our combined findings suggest that Bax and caspases act together to increase mitochondrial $\mathrm{O}_{2}^{--}$production in both NGFmaintained and -deprived SCG neurons. However, the data do not demonstrate a role for caspase 3 in $\mathrm{O}_{2}^{--}$production in the cells under normal circumstances, only that caspase 3 can increase $\mathrm{O}_{2}^{--}$ production when $\mathrm{Bax}$ is present. To definitively test whether caspase 3 activity is required for mitochondrial $\mathrm{O}_{2}^{--}$production in NGF-supported or -deprived SCG neurons, we cultured neurons

$\leftarrow$

(5 $\mu \mathrm{g} / \mathrm{ml})$ for $20 \mathrm{~min}$. Data are normalized to the average cellular autofluorescence intensities measured in NGF-maintained cells exposed to intracellular media containing rhodamine/dextran but not receiving digitonin treatment. Note in the micrographs of the nonpermeabilized cells that the autofluorescence intensity was very weak. The average increased intensity reflects both an increase in the number of cells staining and an increase in individual cell intensity. Cells were excited by a $488 \mathrm{~nm}$ laser line, and emission was in the red channel of the confocal microscope. $n=15$ neurons for each time point. $\boldsymbol{B}$, Digitonin (Dig) treatment had little effect on $\Delta \psi_{m}$. Top, Confocal micrograph of NGF-maintained neurons exposed to TMRM ${ }^{+}(10 \mathrm{~nm}$ for 20 min at $35^{\circ} \mathrm{C}$ after digitonin permeabilization $(5 \mu \mathrm{g} / \mathrm{ml}$ for $20 \mathrm{~min}$ in intracellular medium containing complex I substrates and ADP). Digitonin was washed out twice with the same intracellular medium not containing digitonin and $\mathrm{TMRM}^{+}$. Note punctuate mitochondrial staining. Bottom, Average TMRM ${ }^{+}$intensities in NGF-replete cells exposed to either TMRM ${ }^{+}$ during digitonin loading (second bar) or TMRM ${ }^{+}$after load as described for the micrograph ( $p>0.01$ for with NGF compared with plus NGF and digitonin; $p<0.01$ for the postloaded cells compared with either of the other two conditions). TMRM ${ }^{+}$dye intensities are normalized to the intensity averages of sibling wild-type cultures not receiving apoptotic stimuli (with NGF from time of plating; first bar). $n=193-395$ neurons. C, Digitonin treatment did not cause cytochrome c (Cyto c) to be released from mitochondria. Top, Fluorescent micrograph of NGFdeprived ( $24 \mathrm{~h}$ ) neurons demonstrating the criteria used to score cytochrome c localization by immunocytochemistry. Note the intense punctate staining in the top cell and the faint staining in the bottom one. The intensely stained neuron is representative of cells that were scored as having retained cytochrome in mitochondria. The other neuron is representative of cells scored as having released cytochrome into the cytoplasm in which it appears to be rapidly degraded (Deshmukh and Johnson, 1998; Kirkland and Franklin, 2001; Kirkland et al., 2002, 2007b). Bottom, Twenty minutes of digitonin $(5 \mu \mathrm{g} / \mathrm{ml})$ treatment before fixation did not alter the number of cells scored as having retained cytochrome $c$ in their mitochondria. Digitonin did not affect cytochrome cretention in cells either maintained in or deprived of NGF $(24 \mathrm{~h} ; p>0.01$ for both). $n=3-4$ cultures with $\sim 50$ cells scored in each. $\square$ and identify conditions that were not statistically different $(p>0.01)$. All other conditions were different $(p<0.01)$.
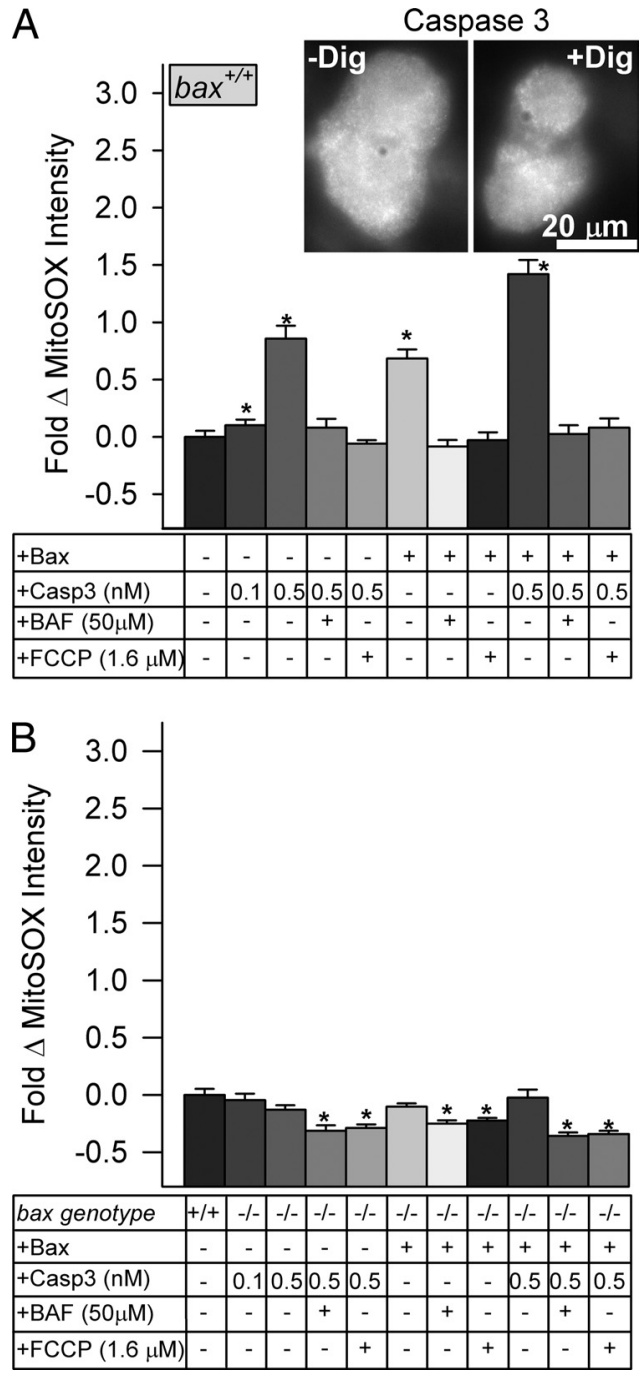

Figure 9. Both Bax and caspase 3 were required to increase $0_{2}^{--}$production in NGFmaintained SCG neurons permeabilized by digitonin. A, Addition of active caspase $3(0.5 \mathrm{nM})$, truncated Bax (amino acids 38-171; 100 nM), or both to NGF-maintained bax ${ }^{+/+}$SCG neurons that had been permeabilized by digitonin (Dig) $(5 \mu \mathrm{g} / \mathrm{ml})$ significantly increased $0_{2}^{--}$levels in them. In each case, this increase was suppressed to near baseline levels by BAF or FCCP ( 50 and $1.6 \mu \mathrm{M}$, respectively). ${ }^{*} p<0.01$, significantly different from control (bar 1). All MitoSOX intensities in BAF- and FCCP-treated cells were significantly lower than intensities in neurons receiving the same treatment without the compounds $(p<0.01) . n=70-465$ neurons. Inset shows immunostaining for caspase 3 in SCG neurons before and after digitonin exposure, indicating that a pool of caspase 3 remains in these cells after permeabilization. One hundred percent of neurons exhibited caspase 3 immunostaining both before and after permeabilization ( $n=150-200$ neurons). The secondary antibody did not stain cells (data not shown). $\boldsymbol{B}$, Addition of neither Bax (amino acids 38-171; $100 \mathrm{~nm}$ ) nor active caspase 3 or both caused increased $0_{2}^{--}$levels in NGF-supported bax ${ }^{-1-}$ cells ( $p>0.1$ compared with control; bar 1 ). ${ }^{*} p<0.03$, MitoSOX intensities in BAF- and FCCP-treated cells were significantly lower than intensities in neurons receiving the same treatment without the compounds. $n=58-623$ neurons. Neurons were permeabilized by exposure for $20 \mathrm{~min}$ to $5 \mu \mathrm{g} / \mathrm{ml}$ digitonin in intracellular buffer containing substrates, MitoSOX (2 $\mu \mathrm{M})$, and the experimental treatments. MitoSOX dye intensities are normalized to the intensity averages of digitonin-permeabilized sibling wild-type cultures (with NGF from time of plating) not exposed to the experimental treatments. Addition of the TCA cycle substrates malate/glutamate to digitonin-permeabilized SCG neurons (supplemental Fig. 8, available at www.jneurosci.org as supplemental material) greatly increased $\mathrm{O}_{2}^{--}$production in NGF-deprived cells but had little effect on the NGF-supported ones.

from mice with genetically altered levels of caspase 3. Figure $10 \mathrm{~A}$ shows that casp 3 deletion slightly decreased $\mathrm{O}_{2}^{--}$production in NGF-supported cells, suggesting a role for this caspase in basal $\mathrm{O}_{2}^{--}$production in these neurons. Figure $10 \mathrm{~B}$ shows that NGF- 

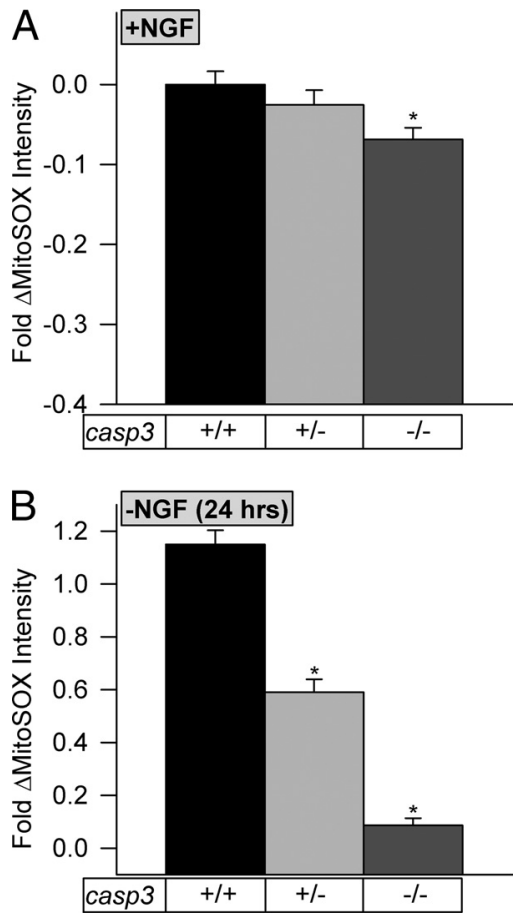

Figure 10. $\quad \mathrm{O}_{2}^{--}$levels were lower in NGF-deprived and -maintained SCG neurons lacking caspase 3. $A$, Genetic deletion of caspase 3 slightly, but significantly, reduced $0_{2}^{--}$levels in NGF-supported casp $3^{-1-}$ SCG neurons. $n=234-559$ neurons. $B$, Genetic reduction or deletion of caspase 3 significantly lowered $0_{2}^{--}$levels in NGF-deprived casp3 $3^{+/-}$and $\operatorname{casp}^{-/-}$ neurons. Cytochrome c was released over the same time course in the $\operatorname{casp}^{-1-}$ neurons as in wild type (data not shown). $n=182-559$ neurons. MitoSOX dye intensities are normalized to the intensity averages of sibling wild-type cultures (with NGF from time of plating). ${ }^{*} p<0.01$ compared with $\operatorname{casp} 3^{+/+}$.

deprived $\operatorname{casp}^{+/-}$cells had reduced $\mathrm{O}_{2}^{--}$levels compared with casp $3^{+/+}$neurons. Rate of cytochrome $c$ release in these cells was the same as in casp $3^{+/+}$neurons (data not shown). There was little increase in $\mathrm{O}_{2}^{--}$production in NGF-deprived casp $3^{-/-}$cells. Therefore, caspase 3 was required for most of the increased Baxdependent mitochondrial $\mathrm{O}_{2}^{--}$production after NGF withdrawal. It was also required for some of the ongoing Bax-dependent $\mathrm{O}_{2}^{--}$ production in neurons not receiving the apoptotic stimulus. However, the decrease in $\mathrm{O}_{2}^{--}$production in the nonapoptotic casp $3^{-1-}$ cells was considerably less than that caused by bax deletion (Fig. 2), indicating that caspase 3 alone could not account for all of the effects of Bax on $\mathrm{O}_{2}^{--}$production in them.

\section{Discussion}

Hockenbery et al. (1993) were the first to demonstrate an effect of Bcl-2 family proteins on cellular oxidative stress when they showed that Bcl-2 has antioxidant activity in cells. Several other groups subsequently reported that different members of the Bcl-2 family can have either antioxidant or pro-oxidant effects (Kowaltowski et al., 2000; Kowaltowski and Fiskum, 2005; Chen and Pervaiz, 2007). We showed that the proapoptotic Bcl-2 family member Bax lies upstream of increased mitochondrial ROS production occurring during the apoptotic death of NGF-deprived SCG and repolarized/serum-starved CG neurons in cell culture (Kirkland et al., 2002). Here we report on an investigation into the mechanisms underlying this phenomenon. During this investigation, we discovered that Bax also lies upstream of most $\mathrm{O}_{2}^{--}$and other ROS produced in nonapoptotic neurons.
We first used the redox-sensitive dyes MitoSOX and CM$\mathrm{H}_{2}$ DCFDA to perform a confocal microscopic analysis of $\mathrm{O}_{2}^{--}$and other ROS in SCG and CG neurons expressing different concentrations of Bax. Bax protein concentration in both cells types was varied by breeding mice expressing different bax gene dosages. The increased levels of MitoSOX-detected $\mathrm{O}_{2}^{--}$and CM$\mathrm{H}_{2}$ DCFDA-detected ROS that occurs in these cells after exposure to an apoptotic stimulus were reduced in neurons having lower Bax concentrations and were nearly abrogated in neurons lacking Bax. Reduction of Bax concentration also decreased $\mathrm{O}_{2}^{--}$and other ROS in cells not receiving apoptotic stimuli. Because the actual degree of the Bax effect on production of $\mathrm{O}_{2}^{--}$and other ROS might be masked as a result of the activity of SOD enzymes, we chemically blocked cytosolic SOD1 activity and genetically reduced or eliminated mitochondrial SOD2 activity. Reduction of the activity of either SOD caused an increase in $\mathrm{O}_{2}^{--}$and other ROS in apoptotic and nonapoptotic $b a x^{+/+}$cells, whereas there was little effect in $b a x^{-1-}$ neurons. These data suggest that almost all $\mathrm{O}_{2}^{--}$and other ROS produced in both SCG and CG neurons lie downstream of Bax, making this protein a major cellular prooxidant in both apoptotic and nonapoptotic cells.

\section{Mechanisms underlying the pro-oxidant effect of Bax}

To investigate mechanisms underlying the effects of Bax on neuronal $\mathrm{O}_{2}^{-}$production, we focused on the SCG paradigm. One possible mechanism by which Bax could elevate mitochondrial $\mathrm{O}_{2}^{--}$production is by increasing mitochondrial mass. However, there were no differences in mitochondrial mass in cells having different bax or sod2 genotypes. Another possible mechanism that might have underlain the elevated levels of mitochondrial $\mathrm{O}_{2}^{--}$production in cells with higher Bax concentrations was hyperpolarization of $\Delta \psi_{m}$ (Starkov et al., 2002). However, $\Delta \psi_{m}$ was actually greater in both apoptotic and nonapoptotic SCG neurons that had lower Bax levels.

The increased ROS in apoptotic HeLa cells lie downstream of caspase activity (Ricci et al., 2003, 2004). Caspases activated by Bax-induced cytochrome $c$ released from mitochondria apparently gain access to the mitochondrial intermembrane space after OMM permeabilization in which they cleave the NDUFS1 subunit of the first respiratory complex (Ricci et al., 2003, 2004). This cleavage augments leakage of electrons from the electron transport chain to $\mathrm{O}_{2}$ to form $\mathrm{O}_{2}^{--}$. We found that NGF-deprived SCG neurons that had the largest ROS increase also had the lowest (most depolarized) $\Delta \psi_{m}$. This finding is consistent with a role for activated caspases causing elevated ROS levels via cleavage of respiratory complex components and subsequent increased leakage of electrons from the transport chain. Also consistent with a role for caspase activity in production of $\mathrm{O}_{2}^{--}$, the broadspectrum caspase inhibitor BAF suppressed the elevated $\mathrm{O}_{2}^{--}$and ROS downstream of $\mathrm{O}_{2}^{--}$in apoptotic SCG neurons (Kirkland et al., 2007b). Using a caspase 3 activity assay, we found that caspase 3 activity increased in these neurons after NGF withdrawal and that BAF blocked this increase (Wright et al., 2007). There was little increase in $\mathrm{O}_{2}^{--}$production in NGF-deprived neurons derived from caspase 3 null animals. Together, the data indicate that caspase 3 is necessary for increased $\mathrm{O}_{2}^{--}$and downstream ROS during the apoptotic death of NGF-deprived SCG neurons.

To explore the roles of Bax and caspases in mitochondrial $\mathrm{O}_{2}^{-}$ production in nonapoptotic SCG neurons, we first treated digitonin-permeabilized cells with active caspase 3. Permeabilization of the plasma membrane with digitonin did not significantly alter $\Delta \psi_{m}$ or cause cytochrome $c$ redistribution, indicating that the mitochondria in these cells remained intact and ener- 
gized. Exposing permeabilized $b a x^{+/+}$cells to caspase 3 caused a large increase in $\mathrm{O}_{2}^{--}$production. In $b a x^{-/-}$cells, this treatment had no effect. When a truncated form of Bax (amino acids 38171 ) that essentially acts like a $\mathrm{BH} 3$-only protein was introduced into the $b_{a x}{ }^{-1-}$ neurons along with active caspase $3, \mathrm{O}_{2}^{--}$production did not increase. This was likely attributable to the inability of truncated Bax to effectively permeabilize the mitochondrial outer membrane in the absence of endogenous Bax and, thus, enable caspase- 3 to access the intermembrane space.

Although the data do not directly address the mechanism by which Bax and caspase 3 coordinated their activities to increase $\mathrm{O}_{2}^{--}$production in nonapoptotic neurons, the most parsimonious explanation is that Bax allowed the caspase 3 access to the mitochondrial intermembrane space in which it cleaved respiratory complexes, causing increased electron leakage and augmented $\mathrm{O}_{2}^{--}$production. There was a low level of caspase 3 activity in nonapoptotic SCG neurons, but deletion of caspase 3 had only a small suppressive effect on basal $\mathrm{O}_{2}^{--}$production in them. This finding suggests that caspase 3 activity was only partially responsible for the effect of $\mathrm{Bax}$ on basal $\mathrm{O}_{2}^{--}$production in nonapoptotic cells. Long-term treatment with BAF suppressed the $\mathrm{O}_{2}^{--}$in nonapoptotic SCG neurons to a greater extent than did caspase 3 deletion, suggesting that caspases in addition to caspase 3 were involved in basal mitochondrial $\mathrm{O}_{2}^{--}$production in these cells.

Little is known about how production of $\mathrm{O}_{2}^{--}$by mitochondria, particularly in nonapoptotic cells, may be regulated. The data we report here suggest that Bax lies upstream of most mitochondrial $\mathrm{O}_{2}^{--}$production in both apoptotic and nonapoptotic SCG and CG neurons. Although most Bax appears to reside in the cytoplasm of healthy cells, a considerable amount is associated with the mitochondria of many nonapoptotic cells, including SCG (Putcha et al., 2000), CG (Desagher et al., 1999), and cortical (Lesuisse and Martin, 2002; Shou et al., 2003) neurons. It seems likely that it is this pool of Bax that exerts the pro-oxidant effect in nonapoptotic neurons reported here. Inducible BH3-only proteins such as Bim can activate Bax during apoptotic death by neutralizing Bax prosurvival relatives or by directly binding to Bax (Green, 2006; Mérino et al., 2009). The BH3-only protein PUMA (p53-upregulated modulator of apoptosis) was shown recently to be a dominant regulator of Bax activation by oxidative stress in cortical neurons (Steckley et al., 2007). Bax can also be transcriptionally regulated (Bouvard et al., 2000). Whether these mechanisms function to alter Bax targeting or concentration within nonapoptotic cells remains to be determined.

Bax is significantly downregulated in the adult rat and mouse brains compared with the newborn brains (Vekrellis et al., 1997; Krajewska et al., 2002; Polster et al., 2003). Although there is considerably less Bax in the adult mouse brain, we have found that detectable amounts do remain (up to 24 months postnatal; data not shown). Several reports indicate that the Bax in the adult rodent nervous system remains functional and can contribute to neuropathologies (Cao et al., 2001; Vila et al., 2001). It is also involved in the naturally occurring programmed death of adultgenerated mouse hippocampal neurons (Sun et al., 2004). Bax is upregulated in Alzheimer's disease brains (Su et al., 1997). Oxidative stress is thought to contribute to the tissue damage occurring in many neuropathologies, including Alzheimer's disease (Pratico et al., 2001; Sherer et al., 2003; Lin and Beal, 2006; Keeney et al., 2006; Abramov et al., 2007; Halliwell and Gutteridge, 2007). It is possible that the pro-oxidant effect of Bax, in addition to or as part of its apoptotic function, contributes to these pathologies. Bax is also widely distributed in many non- neuronal tissues in which it is implicated in various pathologies (Bouvard et al., 2000; Hochhauser et al., 2003; Ben-Ari et al., 2007). Therefore, elucidation of the mechanisms by which Bax regulates neuronal $\mathrm{O}_{2}^{--}$production may contribute to understanding not only neuropathologies but pathologies in many other tissues as well.

In conclusion, we show that Bax lies upstream of production of almost all neuronal $\mathrm{O}_{2}^{--}$and ROS downstream of $\mathrm{O}_{2}^{--}$in both apoptotic and nonapoptotic SCG and CG neurons in cell culture. We also demonstrate that caspase 3 is necessary for most of the effect of $\mathrm{Bax}$ on $\mathrm{O}_{2}^{--}$production in apoptotic SCG neurons but that it is much less important for $\mathrm{O}_{2}^{--}$production in nonapoptotic SCG neurons. However, our data also suggest that caspases other than caspase 3 are involved in the pro-oxidant effect of Bax on nonapoptotic cells.

\section{References}

Abramov AY, Scorziello A, Duchen MR (2007) Three distinct mechanisms generate oxygen free radicals in neurons and contribute to cell death during anoxia and reoxygenation. J Neurosci 27:1129-1138.

Adrain C, Martin SJ (2001) The mitochondrial apoptosome: a killer unleashed by the cytochrome seas. Trends Biochem Sci 26:390-397.

Andreyev AY, Kushnareva YE, Starkov AA (2005) Mitochondrial metabolism of reactive oxygen species. Biochemistry (Mosc) 70:200-214.

Barja G (2004) Free radicals and aging. Trends Neurosci 27:595-600.

Ben-Ari Z, Pappo O, Cheporko Y, Yasovich N, Offen D, Shainberg A, Leshem D, Sulkes J, Vidne BA, Hochhauser E (2007) Bax ablation protects against hepatic ischemia/reperfusion injury in transgenic mice. Liver Transpl 13:1181-1188.

Bouvard V, Zaitchouk T, Vacher M, Duthu A, Canivet M, Choisy-Rossi C, Nieruchalski M, May E (2000) Tissue and cell-specific expression of the p53-target genes: bax, fas, $m d m 2$, and waf1/p21, before and following ionizing irradiation in mice. Oncogene 19:649-660.

Cai J, Jones DP (1998) Superoxide in apoptosis: mitochondrial generation triggered by cytochrome c loss. J Biol Chem 273:11401-11404.

Cao G, Minami M, Pei W, Yan C, Chen D, O’Horo C, Graham SH, Chen J (2001) Intracellular Bax translocation after transient cerebral ischemia: implications for a role of the mitochondrial apoptotic signaling pathway in ischemic neuronal death. J Cereb Blood Flow Metab 21:321-333.

Chen ZX, Pervaiz S (2007) Bcl-2 induces pro-oxidant state by engaging mitochondrial respiration in tumor cells. Cell Death Differ 14:1617-1627.

Danial NN, Korsmeyer SJ (2004) Cell death: critical control points. Cell 116:205-219.

Deckwerth TL, Johnson EM Jr (1993) Temporal analysis of events associated with programmed cell death (apoptosis) of sympathetic neurons deprived of nerve growth factor. J Cell Biol 123:1207-1222.

Deckwerth TL, Elliott JL, Knudson CM, Johnson EM Jr, Snider WD, Korsmeyer SJ (1996) Bax is required for neuronal death after trophic factor deprivation and during development. Neuron 17:401-411.

Desagher S, Osen-Sand A, Nichols A, Eskes R, Montessuit S, Lauper S, Maundrell K, Antonsson B, Martinou JC (1999) Bid-induced conformational change of Bax is responsible for mitochondrial cytochrome $c$ release during apoptosis. J Cell Biol 144:891-901.

Deshmukh M, Johnson EM Jr (1998) Evidence of a novel event during neuronal death: development of competence-to-die in response to cytoplasmic cytochrome c. Neuron 21:695-705.

Deshmukh M, Vasilakos J, Deckwerth TL, Lampe PA, Shivers BD, Johnson EM Jr (1996) Genetic and metabolic status of NGF-deprived sympathetic neurons saved by an inhibitor of ICE-family proteases. J Cell Biol 135:1341-1354.

Deshmukh M, Du C, Wang X, Johnson EM Jr (2002) Exogenous Smac induces competence and permits caspase activation in sympathetic neurons. J Neurosci 22:8018-8027.

Du C, Fang M, Li Y, Li L, Wang X (2000) Smac, a mitochondrial protein that promotes cytochrome-c dependent caspase activation by eliminating IAP inhibition. Cell 102:33-42.

Dugan LL, Creedon DJ, Johnson EM Jr, Holtzman DM (1997) Rapid suppression of free radical formation by nerve growth factor involves the mitogen-activated protein kinase pathway. Proc Natl Acad Sci U S A 94:4086-4091. 
Fiskum G, Craig SW, Decker GL, Lehninger AL (1980) The cytoskeleton of digitonin-treated rat hepatocytes. Proc Natl Acad Sci U S A 77:3430-3434.

Fiskum G, Kowaltowksi AJ, Andreyev AY, Kushnareva YE, Starkov AA (2000) Apoptosis-related activities measured with isolated mitochondria and digitonin-permeabilized cells. Methods Enzymol 322:222-234.

Franklin JL, Sanz-Rodriguez C, Juhasz A, Deckwerth TL, Johnson EM Jr (1995) Chronic depolarization prevents programmed death of sympathetic neurons in vitro but does not support growth: requirement for $\mathrm{Ca}^{2+}$ influx but not Trk activation. J Neurosci 15:643-664.

Goldstein JC, Waterhouse NJ, Juin P, Evan GI, Green DR (2000) The coordinate release of cytochrome $c$ during apoptosis is rapid, complete and kinetically invariant. Nat Cell Biol 2:156-162.

Green DR (2006) At the gates of death. Cancer Cell 9:328-330.

Gdynia G, Grund K, Eckert A, Böck BC, Funke B, Macher-Goeppinger S, Sieber S, Herold-Mende C, Wiestler B, Wiestler OD, Roth W (2007) Basal caspase activity promotes migration and invasiveness in glioblastoma cells. Mol Cancer Res 5:1232-1240.

Halliwell B, Gutteridge JMC (2007) Free radicals in biology and medicine, Ed 4. Oxford: Oxford UP.

He L, Wu X, Meylan F, Olson DP, Simone J, Hewgill D, Siegel R, Lipsky PE (2004) Monitoring caspase activity in living cells using fluorescent proteins and flow cytometry. Am J Pathol 164:1901-1913.

Hochhauser E, Kivity S, Offen D, Maulik N, Otani H, Barhum Y, Pannet H, Shneyvays V, Shainberg A, Goldshtaub V, Tobar A, Vidne BA (2003) Bax ablation protects against myocardial ischemia-reperfusion injury in transgenic mice. Am J Physiol Circ Physiol 284:H2351-H2359.

Hockenbery DM, Oltvai ZN, Yin XM, Milliman CL, Korsmeyer SJ (1993) Bcl-2 functions in an antioxidant pathway to prevent apoptosis. Cell 75:241-251.

Johnson-Cadwell LI, Jekabsons MB, Wang A, Polster BM, Nicholls DG (2007) "Mild uncoupling" does not decrease mitochondrial superoxide levels in cultured cerebellar granule neurons but decreases spare respiratory capacity and increases toxicity to glutamate and oxidative stress. J Neurochem 101:1619-1631.

Karbowski M, Youle RJ (2003) Dynamics of mitochondrial morphology in healthy cells during apoptosis. Cell Death Differ 10:870-880.

Karbowski M, Norris KL, Cleland MM, Jeong SY, Youle RJ (2006) Role of Bax and Bak in mitochondrial morphogensis. Nature 443:658-662.

Keele BB Jr, McCord JM, Fridovich I (1970) Superoxide dismutase from Escherichia coli B. A new manganese-containing enzyme. J Biol Chem 245:6176-6181.

Keeney PM, Xie J, Capaldi RA, Bennett JP Jr (2006) Parkinson's disease brain mitochondrial complex I has oxidatively damaged subunits and is functionally impaired and misassembled. J Neurosci 26:5256-5264.

Kirkland RA, Franklin JL (2001) Evidence for redox regulation of cytochrome $c$ release during programmed neuronal death: antioxidant effects of protein synthesis and caspase inhibition. J Neurosci 21:1949-1963.

Kirkland RA, Franklin JL (2007a) Bax affects production of reactive oxygen by the mitochondria of nonapoptotic neurons. Exp Neurol 204:458-461.

Kirkland RA, Windelborn JA, Kasprzak JM, Franklin JL (2002) A Baxinduced pro-oxidant state is critical for cytochrome c release during programmed neuronal death. J Neurosci 22:6480-6490.

Kirkland RA, Saavedra GM, Franklin JL (2007b) Rapid activation of antioxidant defenses by nerve growth factor suppresses reactive oxygen species during neuronal apoptosis: evidence for a role in cytochrome $c$ redistribution. J Neurosci 27:11315-11326.

Knudson CM, Tung KS, Tourtellotte WG, Brown GA, Korsmeyer SJ (1995) Bax-deficient mice with lymphoid hyperplasia and male germ cell death. Science 270:96-99.

Kober T, König I, Weber M, Kojda G (2003) Diethyldithiocarbamate inhibits the catalytic activity of xanthine oxidase. FEBS Lett 551:99-103.

Kokoszka JE, Coskun P, Esposito LA, Wallace DC (2001) Increased mitochondrial oxidative stress in the SOD2 $(+/-)$ mouse results in the agerelated decline of mitochondrial function culminating in increased apoptosis. Proc Natl Acad Sci U S A 98:2278-2283.

Kowaltowski AJ, Fiskum G (2005) Redox mechanisms of cytoprotection by Bcl-2. Antioxid Redox Signal 7:508-514.

Kowaltowski AJ, Vercesi AE, Fiskum G (2000) Bcl-2 prevents mitochondrial permeability transition and cytochrome $c$ release via maintenance of reduced pyridine nucleotides. Cell Death Differ 7:903-910.

Krajewska M, Mai JK, Zapata JM, Ashwell KW, Schendel SL, Reed JC, Krajewski S (2002) Dynamics of expression of apoptosis-regulatory proteins Bid, Bcl-2, Bcl-x, Bax, and Bak during development of murine nervous system. Cell Death Differ 9:145-157.

Leitch JM, Yick PJ, Culotta VC (2009) The right to choose: multiple pathways for activating copper, zinc superoxide dismutase. J Biol Chem 284:24679-24683.

Lesuisse C, Martin LJ (2002) Long-term culture of mouse cortical neurons as a model for neuronal development, aging, and death. J Neurobiol 51:9-23.

Li LY, Luo X, Wang X (2001) Endonuclease G is an apoptotic DNAse when released from mitochondria. Nature 412:95-99.

Li P, Nijhawan D, Budihardjo I, Srinivasula SM, Ahmad M, Alnemri ES, Wang X (1997) Cytochrome c and dATP-dependent formation of Apaf$1 /$ caspase- 9 complex initiates an apoptotic protease cascade. Cell 91:479-489.

Li Z, Jo J, Jia J, Lo S, Whitcomb DJ, Jiao S, Cho K, Sheng M (2010) Caspase-3 activation via mitochondria is required for long-term depression and AMPA receptor internalization. Cell 141:859-871.

Lin MT, Beal MF (2006) Mitochondrial dysfunction and oxidative stress in neurodegenerative diseases. Nature 443:787-795.

Liu TH, Beckman JS, Freeman BA, Hogan EL, Hsu CY (1989) Polyethylene glycol-conjugated superoxide dismutase and catalase reduce ischemic brain injury. Am J Physiol 256:H589-H593.

Liu Y, Fiskum G, Schubert D (2002) Generation of reactive oxygen species by the mitochondrial electron transport chain. J Neurochem 80:780-787.

Lucken-Ardjomande S, Montessuit S, Martinou JC (2008) Contributions to Bax insertion and oligomerization of lipids of the mitochondrial outer membrane. Cell Death Differ 15:929-937.

Maklashina E, Ackrell BAC (2004) Is defective electron transport at the hub of aging? Aging Cell 3:21-27.

Martin DP, Schmidt RE, DiStefano PS, Lowry OH, Carter JG, Johnson EM Jr (1988) Inhibitors of protein synthesis and RNA synthesis prevent neuronal death caused by nerve growth factor deprivation. J Cell Biol 106:829-844.

McCord JM, Fridovich I (1969) Superoxide dismutase an enzymatic function for erythrocuprein (hemocuprein). J Biol Chem 244:6049-6055.

McCord JM, Boyle JA, Day ED, Rizzolo LJ, Salin ML (1977) Superoxide and superoxide dismutases (Michelson AM, McCord JM, Fridovich I, eds). London: Academic.

Melov S (2004) Modeling mitochondrial function in aging neurons. Trends Neurosci 10:600-606.

Melov S, Coskun P, Patel M, Tuinstra R, Cottrell B, Jun AS, Zastawny TH, Dizdaroglu M, Goodman SI, Huang TT, Miziorko H, Epstein CJ, Wallace DC (1999) Mitochondrial disease in superoxide dismutase 2 mutant mice. Proc Natl Acad Sci U S A 96:846-851.

Mérino D, Giam M, Hughes PD, Siggs OM, Heger K, O’Reilly LA, Adams JM, Strasser A, Lee EF, Fairlie WD, Bouillet P (2009) The role of BH3-only protein Bim extends beyond inhibiting Bcl-2-like prosurvival proteins. J Cell Biol 186:355-362.

Miller RA (2004) “Accelerated aging": a primrose path to insight? Aging Cell 3:47-51.

Miller TM, Johnson EM Jr (1996) Metabolic and genetic analysis of apoptosis in potassium/serum-deprived rat cerebellar granule cells. J Neurosci 16:7487-7495.

Miller TM, Moulder KL, Knudson CM, Creedon DJ, Deshmukh M, Korsmeyer SJ, Johnson EM Jr (1997) Bax deletion further orders the cell death pathway in cerebellar granule cells and suggests a caspaseindependent pathway in cell death. J Cell Biol 139:205-217.

Misra HP (1979) Reaction of copper-zinc superoxide dismutase with diethyldithiocarbamate. J Biol Chem 254:11623-11628.

Nhan TQ, Liles WC, Schwartz SM (2006) Physiological functions of caspases beyond cell death. Am J Pathol 169:729-737.

Nicholls DG, Budd SL (2000) Mitochondria and neuronal survival. Physiol Rev 80:315-360.

Nicholls DG, Ferguson SJ (2002) Bioenergetics 3. London: Academic.

Nicholls DG, Ward MW (2000) Mitochondrial membrane potential and cell death: mortality and millivolts. Trends Neurosci 23:166-174.

O'Hare MJ, Hou ST, Morris EJ, Cregan SP, Xu Q, Slack RS, Park DS (2000) Induction and modulation of cerebellar granule neuron death by E2F-1. J Biol Chem 275:25358-25364.

Pollack M, Phaneuf S, Dirks A, Leeuwenburgh C (2002) The role of apoptosis in the normal aging brain, skeletal muscle, and heart. Ann NY Acad Sci 959:93-107. 
Polster BM, Robertson CL, Bucci CJ, Suzuki M, Fiskum G (2003) Postnatal brain development and neural cell differentiation modulate mitochondrial Bax and $\mathrm{BH} 3$ peptide-induced cytochrome $c$ release. Cell Death Differ 10:365-370.

Praticò D, Uryu K, Leight S, Trojanowski JQ, Lee VM (2001) Increased lipid peroxidation precedes amyloid plaque formation in an animal model of Alzheimer amyloidosis. J Neurosci 21:4183-4187.

Priault M, Cartron PF, Camougrand N, Antonsson B, Vallette FM, Manon S (2003) Investigation of the role of the c-terminus of Bax and of tc-Bid on Bax interaction with yeast mitochondria. Cell Death Differ 10:1068-1077.

Punchard NA, Kelly FJ (1996) Free radicals a practical approach. Oxford: Oxford UP.

Putcha GV, Deshmukh M, Johnson EM Jr (2000) Inhibition of apoptotic signaling cascades causes loss of trophic factor dependence during neuronal maturation. J Cell Biol 149:1011-1018.

Qian S, Wang W, Yang L, Huang HW (2008) Structure of transmembrane pore induced by Bax-derived peptide: evidence for lipidic pores. Proc Natl Acad Sci U S A 105:17379-17383.

Ricci JE, Gottlieb RA, Green DR (2003) Caspase-mediated loss of mitochondrial function and generation of reactive oxygen species during apoptosis. J Cell Biol 160:65-75.

Ricci JE, Muñoz-Pinedo C, Fitzgerald P, Bailly-Maitre B, Perkins GA, Yadava N, Scheffler IE, Ellisman MH, Green DR (2004) Disruption of mitochondrial function during apoptosis is mediated by caspase cleavage of the p75 subunit of complex I of the electron transport chain. Cell 117:773-786.

Robinson KM, Janes MS, Pehar M, Monette JS, Ross MF, Hagen TM, Murphy MP, Beckman JS (2006) Selective fluorescent imaging of superoxide in vivo using ethidium-based probes. Proc Natl Acad Sci USA 103: $15038-15043$

Ross MF, Kelso GF, Blaikie FH, James AM, Cochemé1 HM, Filipovska A, Da Ros T, Hurd TR, Smith RAJ, Murphy MP (2005) Lipophilic triphenylphosphonium cations as tools in mitochondrial bioenergetics and free radical biology. Biochemistry (Mosc) 70:222-230.

Royall JA, Ischiropoulos H (1993) Evaluation of 2',7'-dichlorofluorescin and dihydrorhodamine 123 as fluorescent probes for intracellular $\mathrm{H}_{2} \mathrm{O}_{2}$ in cultured endothelial cells. Arch Biochem Biophys 302:348-355.

Sevilla F, López-Gorgé J, Del Río LA (1982) Characterization of a manganese superoxide dismutase from the higher plant pisum sativum. Plant Physiol 70:1321-1326.

Sherer TB, Betarbet R, Testa CM, Seo BB, Richardson JR, Kim JH, Miller GW, Yagi T, Matsuno-Yagi A, Greenamyre JT (2003) Mechanism of toxicity in rotenone models of Parkinson's disease. J Neurosci 23:10756-10764.

Shou Y, Li L, Praghakaran K, Borowitz JL, Isom GE (2003) P38 mitogenactivated protein kinase regulates Bax translocation in cyanide-induced apoptosis. Toxicol Sci 75:99-107.

Starkov AA, Polster BM, Fiskum G (2002) Regulation of hydrogen peroxide production by brain mitochondria by calcium and Bax. J Neurochem 83:220-228.

Steckley D, Karajgikar M, Dale LB, Fuerth B, Swan P, Drummond-Main C, Poulter MO, Ferguson SS, Strasser A, Cregan SP (2007) Puma is a dominant regulator of oxidative stress induced Bax activation and neuronal apoptosis. J Neurosci 27:12989-12999.

Su JH, Deng G, Cotman CW (1997) Bax protein expression is increased in Alzheimer's brain: correlation with DNA damage, Bcl-2 expression, and brain pathology. J Neuropath Exp Neurol 56:86-93.

Sun W, Winseck A, Vinsant S, Park OH, Kim H, Oppenheim RW (2004) Programmed cell death of adult-generated hippocampal neurons is mediated by the proapoptotic gene bax. J Neurosci 24:11205-11213.

Suzuki Y, Imai Y, Nakayama H, Takahashi K, Takio K, Takahashi R (2001) A serine protease, HtrA2, is released from the mitochondria and interacts with XIAP, inducing cell death. Mol Cell 8:613-621.

Tan S, Sagara Y, Liu Y, Maher P, Schubert D (1998) The regulation of reactive oxygen species production during programmed cell death. J Cell Biol 141:1423-1432.

Turrens JF (1997) Superoxide production by the mitochondrial respiratory chain. Bioscience Rep 17:3-8.

Valentijn AJ, Upton JP, Bates N, Gilmore AP (2008) Bax targeting to mitochondria occurs via both tail anchor-dependent and -independent mechanisms. Cell Death Differ 15:1243-1254.

Vaughn AE, Deshmukh M (2007) Essential postmitochondrial function of p53 uncovered in DNA damage-induced apoptosis in neurons. Cell Death Differ 14:973-981.

Vekrellis K, McCarthy MJ, Watson A, Whitfield J., Rubin LL, Ham J (1997) Bax promotes neuronal cell death and is downregulated during the development of the nervous system. Development 124: 1239-1249.

Vila M, Jackson-Lewis V, Vukosavic S, Djaldetti R, Liberatore G, Offen D Korsmeyer SJ, Przedborski S (2001) Bax ablation prevents dopaminergic neurodegeneration in the 1-methyl-4-phenyl-1,2,3,6-tetrahydropyridine mouse model of Parkinson's disease. Proc Natl Acad Sci U S A 98:2837-2842.

Wright KM, Vaughn AE, Deshmukh M (2007) Apoptosome dependent caspase-3 activation pathway is nonredundant and necessary for apoptosis in sympathetic neurons. Cell Death Differ 14:625-633.

Yousefi S, Conus S, Símon HU (2003) Cross-talk between death and survival pathways. Cell Death Differ 10:861-863.

Zhao H, Kalivendi S, Zhang H, Joseph J, Nithipatikom K, Vásquez-Vivar J, Kalyanaraman B (2003) Superoxide reacts with hydroethidine but forms a fluorescent product that is distinctly different from ethidium: potential implications in intracellular fluorescence detection of superoxide. Free Radic Biol Med 34:1359-1368.

Zhao H, Joseph J, Fales HM, Sokoloski EA, Levine RL, Vasquez-Vivar J, Kalyanaraman B (2005) Detection and characterization of the product of hydroethidine and intracellular superoxide by HPLC and limitations of fluorescence. Proc Natl Acad Sci U S A 102:5727-5732. 